\title{
Sulbactam-enhanced cytotoxicity of doxorubicin in breast cancer cells
}

\author{
Shao-hsuan Wen ${ }^{1 \dagger}$, Shey-chiang Su${ }^{2 \dagger}$, Bo-huang Liou ${ }^{3}$, Cheng-hao Lin ${ }^{1}$ and Kuan-rong Lee ${ }^{1 *}$
}

\begin{abstract}
Background: Multidrug resistance (MDR) is a major obstacle in breast cancer treatment. The predominant mechanism underlying MDR is an increase in the activity of adenosine triphosphate (ATP)-dependent drug efflux transporters. Sulbactam, a $\beta$-lactamase inhibitor, is generally combined with $\beta$-lactam antibiotics for treating bacterial infections. However, sulbactam alone can be used to treat Acinetobacter baumannii infections because it inhibits the expression of ATP-binding cassette (ABC) transporter proteins. This is the first study to report the effects of sulbactam on mammalian cells.

Methods: We used the breast cancer cell lines as a model system to determine whether sulbactam affects cancer cells. The cell viabilities in the present of doxorubicin with or without sulbactam were measured by MTT assay. Protein identities and the changes in protein expression levels in the cells after sulbactam and doxorubicin treatment were determined using LC-MS/MS. Real-time reverse transcription polymerase chain reaction (real-time RT-PCR) was used to analyze the change in mRNA expression levels of $A B C$ transporters after treatment of doxorubicin with or without sulbactam. The efflux of doxorubicin was measures by the doxorubicin efflux assay.

Results: MTT assay revealed that sulbactam enhanced the cytotoxicity of doxorubicin in breast cancer cells. The results of proteomics showed that $A B C$ transporter proteins and proteins associated with the process of transcription and initiation of translation were reduced. The mRNA expression levels of ABC transporters were also decreased when treated with doxorubicin and sulbactam. The doxorubicin efflux assay showed that sulbactam treatment inhibited doxorubicin efflux.

Conclusions: The combination of sulbactam and doxorubicin enhances the cytotoxicity of doxorubicin in the breast cancer cells by inhibiting the expression of $A B C$ transporter proteins and proteins associated with the process of transcription and initiation of translation, and blocking the efflux of doxorubicin. Co-treatment of doxorubicin and sulbactam can be used in breast cancer treatment to decrease the prescribed dose of doxorubicin to avoid the adverse effects of doxorubicin.
\end{abstract}

Keywords: Sulbactam, Breast cancer, ABC transporters, Doxorubicin, Proteomics, Inhibitors

\footnotetext{
*Correspondence: krlee@mx.nthu.edu.tw

†Shao-Hsuan Wen and Shey-chiang Su contributed equally for this paper

${ }^{1}$ Department of Molecular Medicine and Institute of Life Science,

National Tsing Hua University, No. 101, Section 2, Kuang-Fu Road,

Hsinchu 30013, Taiwan, ROC

Full list of author information is available at the end of the article
} 


\section{Background}

Breast cancer, the most common cancer in women, annually affects 1.8 million women worldwide [1]. Approximately $12 \%$ of women in the United States are estimated to receive diagnoses of breast cancer in their lifetime [2]. Breast cancer is classified into three subtypes according to the expression of receptors: hormone (estrogen and progesterone)-receptor-positive breast cancer, human epidermal growth factor receptor 2 (HER2)-positive breast cancer, and triple-negative breast cancer (TNBC; lacking hormone receptors as well as HER2) [3]. Patients with TNBC exhibit a high risk of early tumor recurrence and poor prognosis [4]. Chemotherapy is a principal treatment for breast cancer, but resistance to chemotherapy-occurring in at least a quarter of all cases-is a major problem in breast cancer management, causing treatment failure in more than $90 \%$ of patients with metastatic cancers [5-8]. The mechanisms underlying resistance in different breast cancer subtypes are diverse, complex, and unclear. Cancer cells may develop resistance to a specific class of cytotoxic drugs owing to changes in target proteins and in cellular biological activities affecting the efficacy of the drugs. The changes include increased repair of DNA damage and decreased apoptosis, membrane permeability, and drug metabolism. Furthermore, the uptake of water-soluble drugs decreases due to a decrease in the expression of transporter proteins responsible for drugs to enter the cells and the energy-dependent efflux of hydrophobic drugs increases, for instance, through increased expression of adenosine triphosphate (ATP)-binding cassette (ABC) transporter proteins [9-15].

Doxorubicin, an anthracycline antibiotic, has been considered one of the most effective agents in breast cancer treatment since the 1970s [16]. Doxorubicin mainly intercalates between DNA bases and subsequently inhibits topoisomerase II activity, thus impairing DNA synthesis [17]. Doxorubicin also generates free radicals, which damage DNA and cell membranes [18]. Doxorubicin enters the cells through passive diffusion and accumulates intracellularly, particularly in the nuclear compartments [19]. However, doxorubicin is nonselective toward cancer cells; thus, it causes toxicity in the heart, brain, liver, and kidneys $[19,20]$. The most prominent adverse event is life-threatening cardiotoxicity, which limits the prescribed dose of doxorubicin [20]. Doxorubicin resistance is another crucial cause of treatment failure [3]. The reported response rates to doxorubicin as a single agent for breast cancer treatment were $43 \%$ and $28 \%$ in patients who were exposed to doxorubicin for the first time and those who had been exposed to the drug for more than once, respectively. Thus, nearly $50 \%$ of the treated patients developed resistance to doxorubicin, making resistance the major cause of treatment failure [21]. The predominant mechanism underlying resistance to doxorubicin in breast cancer cells is the overexpression of a few $A B C$ transporter proteins that increase doxorubicin efflux, thus decreasing intracellular drug concentrations $[3,9,22]$. Other mechanisms underlying doxorubicin resistance include alterations in cellular signaling pathways, leading to failure of apoptosis, and changes in gene expression, resulting in a chemoresistant phenotype [3, 19].

Increased expression of $\mathrm{ABC}$ transporter proteins has been correlated with poor clinical prognosis in patients with breast cancer of any subtype [23, 24]. The human genome has 49 members of the $\mathrm{ABC}$ transporter family, divided into seven subfamilies (ABCA-ABCG) based on their sequence similarities [25]. These membrane proteins actively pump various structurally and functionally diverse amphipathic anticancer drugs from inside the tumor cells to the outside, thereby decreasing intracellular drug concentrations and causing chemotherapeutic drug resistance $[9,10]$. The primary members of the $\mathrm{ABC}$ transporter family leading to doxorubicin resistance in cancer cells are the $\mathrm{ABCBs}$, the ABCCs [also known as multidrug resistance (MDR)-associated proteins], and ABCG2 (also known as breast cancer resistance protein, mitoxantrone resistance protein, or placenta-specific $\mathrm{ABC}$ transporter) [9, 26, 27]. Among the aforementioned $\mathrm{ABC}$ transporter proteins, ABCB1 [a P-glycoprotein, (p-gp)], ABCC1, and ABCG2 have been extensively characterized in breast cancers [23, 24, 28, 29]. Inhibitors of the $\mathrm{ABC}$ transporter proteins activity were used to overcome $\mathrm{ABC}$ transporter-mediated MDR for obstructing the expression of the transporter proteins or inhibiting their function. For example, a combination of doxorubicin and verapamil, a P-gp inhibitor, can reverse the resistance of breast cancer cells to doxorubicin [30]. However, verapamil can potentiate the cardiotoxicity of doxorubicin [31]. Over the past decades, numerous inhibitors of MDR-related $\mathrm{ABC}$ transporter proteins have been developed and identified. However, the development of most inhibitors has been discontinued because of their low binding affinity, toxicity, detrimental pharmacokinetic interactions, and low patient survival advantages [9, 32]. Furthermore, the expression patterns of $\mathrm{ABC}$ transporter proteins in breast cancer cells are heterogeneous; thus, the efficacy of inhibitors specific to some $\mathrm{ABC}$ transporter proteins is low [33].

Sulbactam, a $\beta$-lactamase inhibitor belonging to Ambler class $\mathrm{A}$, is administered along with $\beta$-lactam antibiotics (e.g., ampicillin and penicillin) to prevent the hydrolysis of the antibiotics by bacterial $\beta$-lactamases. Sulbactam inhibits the activity of $\beta$-lactamases by irreversibly binding to their active sites. The $\beta$-lactam $/ \beta$-lactamase 
inhibitor combination has been approved by the US Food and Drug Administration for treating dermatological, gynecological, and intraabdominal infections [34]. Although sulbactam has relatively low intrinsic biological activity, it has inherent activity against some bacterial species, including Neisseria gonorrhoeae, Bacteroides fragilis, and Acinetobacter spp. [35, 36]. Preliminary in vitro experiments have demonstrated that sulbactam kills bacteria by binding to the penicillin-binding proteins (PBPs) of Acinetobacter spp. and downregulating the expression of PBP1 and PBP3 [35, 37]. Furthermore, sulbactam reduces the expression of the $A B C$ transporter proteins in Acinetobacter baumannii [38]. The ABC transporter superfamilies are highly conserved protein families, and their structural features and mechanisms of action have been conserved from prokaryotes to humans $[39,40]$. Thus, we hypothesized that if sulbactam can reduce the expression of $\mathrm{ABC}$ transporter proteins in breast cancer cells, then it can reduce the efflux of doxorubicin from breast cancer cells and enhance its efficacy.

\section{Materials and methods Reagents}

Doxorubicin hydrochloride was purchased from SigmaAldrich (St. Louis, MO, USA). Sulbactum sodium was obtained from TTY Biopharm (Taiwan). Verapamil was obtained from Orion Pharma (Espoo, Finland).

\section{Cell lines and cell culture}

The breast carcinoma cell lines MDA-MB-231, MDAMB-435, MDA-MB-453, and MDA-MB-468 were maintained in Dulbecco's modified Eagle's medium (DMEM) (Hyclone, Thermo Fisher Scientific Inc. Waltham, MA, USA) containing $10 \%$ fetal bovine serum (FBS; GibcoBRL, Rockville, MD, USA) and 100 units $/ \mathrm{mL}$ penicillin-streptomycin (Gibco-BRL). The breast carcinoma cell lines MCF-7, BT474, and T-47D were maintained in Roswell Park Memorial Institute (RPMI)-1640 medium (Hyclone) containing 10\% FBS and 100 units/mL penicillin-streptomycin. The human breast epithelial cell line MCF-10A was maintained in DMEM/F12 medium containing 5\% horse serum (Invitrogen, Carlsbad, CA, USA), $20 \mathrm{ng} / \mathrm{mL}$ epithelial growth factor (Peprotech, Rocky Hill, $\mathrm{NJ}$, USA), $0.5 \mu \mathrm{g} / \mathrm{mL}$ hydrocortisone (Sigma-Aldrich), $10 \mu \mathrm{g} / \mathrm{mL}$ insulin (Sigma-Aldrich), and 100 units $/ \mathrm{mL}$ penicillin-streptomycin. All cell lines were incubated at $37^{\circ} \mathrm{C}$ and $5 \% \mathrm{CO}_{2}$.

\section{MTT assay}

The MTT (3-(4,5-dimethylthiazol-2-yl)-2,5-diphenyltetrazolium bromide) assay was used to access cytotoxicity. The cells were grown in 96-well plates at a density of $1.5 \times 10^{4}$ cells/well. To determine the toxicities of sulbactam and doxorubicin, sulbactam and doxorubicin were added at various concentrations into the wells. At $48 \mathrm{~h}$ after treatment, the medium in the wells was replaced with $100 \mu \mathrm{L} /$ well of medium containing $0.5 \mu \mathrm{g} / \mu \mathrm{L}$ MTT and incubated for $4 \mathrm{~h}$. Subsequently, the medium was removed and $100 \mu \mathrm{L}$ DMSO was added in each well to dissolve the formazan crystals. The absorbance of the samples was measured at 550 and $655 \mathrm{~nm}$ as the test and reference wavelengths, respectively, by using an iMark microplate reader (Bio-Rad, Hercules, CA, USA). To determine the effects of the combination of sulbactam and doxorubicin, various concentrations of doxorubicin were added to the medium containing $2 \mathrm{mM}$ sulbactam in 96-well plates seeded with the breast cancer cells. The MTT assay was performed as described above. The cytotoxicity was expressed as relative viability (percentage of control). The percentage of cell survival in the negative control (without sulbactam and doxorubicin treatment) was considered 100. Relative viability $=[$ (experimental absorbance - background absorbance)/(absorbance of untreated control-background absorbance) $] \times 100 \%$. The half maximal inhibitory concentration $\left(\mathrm{IC}_{50}\right)$ values of sulbactam, doxorubicin, and the combinations of sulbactam and doxorubicin were calculated using the survival curves by using the Bliss method. The degree of resistance was calculated by determining the ratio of the $\mathrm{IC}_{50}$ of the cells treated with sulbactam-doxorubicin combinations to that of the cells treated with doxorubicin alone.

\section{Real-time RT-PCR}

Total RNA was extracted using TriZol (Invitrogen) and reverse transcribed (SuperScript III reverse transcriptase, Invitrogen and ExcelRT Reverse Transcriptase RP1000, SMOBIO, Taiwan). Real-time reverse transcription polymerase chain reaction (Real-time RT-PCR) was performed on ABI StepOnePlus ${ }^{\mathrm{TM}}$ Real-Time system using the SYBR Green PCR Master Mix (Applied Biosystems). The sequences of the PCR primers were listed in Table 1. The condition for PCR was $95^{\circ} \mathrm{C}$ for $10 \mathrm{~min}$, followed by 40 rounds of $95{ }^{\circ} \mathrm{C}$ for $15 \mathrm{~s}$ and $60^{\circ} \mathrm{C}$ for $1 \mathrm{~min}$. The data were analyzed by StepOne Software v2.2.2.

\section{Efflux assay of doxorubicin}

The MDA-MB-453 and MDA-MB-468 cells were seeded on coverslips in 12-well plates at a concentration of $1 \times 10^{5}$ cells/well and grown for $16 \mathrm{~h}$. On the following day, the cells were washed with phosphate buffered saline (PBS) and incubated with $2 \mathrm{mM}$ sulbactam or $5 \mu \mathrm{M}$ verapamil for $30 \mathrm{~min}$ before treating them with $2 \mu \mathrm{M}$ doxorubicin for $2 \mathrm{~h}$. The cells were subsequently incubated in a doxorubicin-free medium for $0,8,12$, and $16 \mathrm{~h}$. Images 
Table 1 List of primers of ABC transporters used for real-time RT-PCR

\begin{tabular}{llll}
\hline Gene & RefSeq & Forward oligo sequence & Reverse oligo sequence \\
\hline ABCB1 & NM_000927 & AGCTCGTGCCCTTGTTAGACA & GTCCAGGGCTTCTTGGACAA \\
ABCB5 & NM_178559 & CACAAAAGGCCATTCAGGCT & GCTGAGGAATCCACCCAATCT \\
ABCB8 & NM_007188 & CATCGCCTTCAACTGCATGG & GACCTTTGCACTGTCTGGGA \\
ABCB10 & NM_012089 & TGCGGTTGGATTTCTCACGA & CACACAGAAACACGGCACTG \\
ABCC1 & NM_004996 & CGCTCTGGGACTGGAATGT & AGGTAAAAACAAGGCACCCA \\
ABCC2 & NM_000392 & TGCACAAGCAACTGCTGAAC & CCTCTGGCCTATGCTCAGGTT \\
ABCC3 & NM_020038 & ACCCAGTTGATACCTGCACTGT & GGACCCTGGTGTAGTCCATGA \\
ABCC4 & NM_005845 & TTGGACACGGTAACTGTTGCA & GGAATGTCGGTTAGAGGTTGG \\
ABCC5 & NM_005688 & ATTTGGACCCCTTCAACCAGTAC & GGTAGCTGAGCAATACATTCTTTCAT \\
ABCC10 & NM_033450 & GGCCCTGTCCTTATGTAGGC \\
ABCG2 & CM_004827 & GTGTTGTTGGTGCTCTTCC & GTGGTCGTCAGGAAGAAGAG \\
GAPDH & NM_002046 & TATAGCTCAGATCATTGTCACAGTC & TCGCCTGGAAGATGGTG \\
\hline
\end{tabular}

were obtained using a LSM 780 confocal microscope (Zeiss) and analyzed using ZEN 2012.

\section{Gel electrophoresis}

The equivalence of the human cell lines was analyzed through $12.5 \%$ sodium dodecyl sulfate-polyacrylamide gel electrophoresis (SDS-PAGE). The gels were then stained using the VisPRO protein stain kit (Visual Protein Biotech, Taiwan) for $5 \mathrm{~min}$. After staining, the gels were washed with Milli-Q water and stored at $4{ }^{\circ} \mathrm{C}$ until in-gel digestion.

\section{In-gel digestion}

The gel lanes corresponding to the samples were cut into five slices, and each slice was subjected to in-gel digestion according to the method of Shevchenko [41]. Briefly, the slices were washed thrice with $50 \mathrm{mM}$ ammonium bicarbonate $(\mathrm{pH}$ 7.9) and dehydrated using $50 \mathrm{mM}$ $\mathrm{AMBC}+50 \%$ acetonitrile (ACN). Subsequently, the cysteine bonds were reduced after treatment with $10 \mathrm{mM}$ dithiothreitol for $1 \mathrm{~h}$ at $56{ }^{\circ} \mathrm{C}$ and alkylated using $50 \mathrm{mM}$ 4-vinylpyridine for $45 \mathrm{~min}$ at room temperature in the dark. After two subsequent wash-dehydration cycles, the slices were dried for $10 \mathrm{~min}$ in a vacuum centrifuge (ThermoFisher, Breda, Netherlands) and incubated overnight with $6.25 \mathrm{ng} / \mu \mathrm{L}$ trypsin in $50 \mathrm{mM} \mathrm{AMBC}$ at $25^{\circ} \mathrm{C}$. The resulting peptides were extracted once in $100 \mu \mathrm{L}$ of $1 \%$ formic acid and then two times in $100 \mu \mathrm{L}$ of $50 \% \mathrm{ACN}$ in $5 \%$ formic acid. The volume was reduced to $50 \mu \mathrm{L}$ in a vacuum centrifuge before liquid chromatography (LC)tandem mass spectrometry (MS/MS) analysis.

\section{LC-MS/MS}

The peptides were separated using an Ultimate 3000 nano LC system (Dionex LC-Packings, Amsterdam,
Netherlands) equipped with a $20 \mathrm{~cm} \times 75 \mu \mathrm{m}$ internal diameter (i.d.) fused-silica column custom packed with 3- $\mu \mathrm{m}$ 120- $\AA$ ReproSil Pur C18 aqua (Dr. Maisch, GMBH, Ammerbuch-Entringen, Germany). After injection, the peptides were delivered into the column at a flowrate of $30 \mu \mathrm{L} / \mathrm{min}$ and trapped on a $5 \mathrm{~mm} \times 300 \mu \mathrm{m}$ i.d. Pepmap C18 cartridge (Dionex LC-Packings), which were then eluted by $2 \%$ buffer $\mathrm{B}(80 \% \mathrm{ACN}$ and $0.05 \%$ formic acid in Milli-Q water) and separated at $300 \mathrm{~nL} / \mathrm{min}$ in a $10 \%-40 \%$ buffer B gradient within $60 \mathrm{~min}$. The eluting peptides were ionized at $1.7 \mathrm{kV}$ in a Nanomate Triversa Chip-based nanospray source by using a Triversa LC coupler (Advion, Ithaca, NJ, USA). Intact peptide mass spectra and fragmentation spectra were acquired on a LT QFT hybrid mass spectrometer (Thermo Fisher, Bremen, Germany). The intact masses were measured at a resolution of 50,000 in the ion cyclotron resonance (ICR) cell by using a target value of $1 \times 10^{6}$ charges. Simultaneously, following an FT prescan, the five highest peptide signals (charge states $2+$ and higher) were submitted for $\mathrm{MS} / \mathrm{MS}$ in the linear ion trap (3-AMU isolation width, $30 \mathrm{~ms}$ activation, 35\% normalized activation energy, 0.25 Q-value, and 5000-count threshold. Dynamic exclusion was applied with a repeat count of 1 and an exclusion time of $30 \mathrm{~s}$.

\section{Results}

Sulbactam potentiates doxorubicin sensitivity in breast cancer cells

To determine whether sulbactam enhances the cytotoxicity of doxorubicin, MCF-10A (normal), BT474 (ER/PR+, Her2+), MCF-7 (ER/PR+, Her2-), MDAMB-231 (triple negative), MDA-MB-361 (ER/PR+, Her2+), MDA-MB-435 (ER/PR-, Her2+), MDAMB-453 (triple negative), MDA-MB-468 (triple 
negative), and T47D (ER/PR+, Her2-) cell lines were treated for $48 \mathrm{~h}$ with $0,0.1,0.5,1,5$, and $10 \mu \mathrm{M}$ doxorubicin in the presence or absence of $2 \mathrm{mM}$ sulbactam for $48 \mathrm{~h}$. Cell viabilities were measured through the MTT assay. Doxorubicin exerted cytotoxic effects in a dose-dependent manner against all the cell lines (Fig. 1). When the cells were treated with doxorubicin alone, the viability of the MDA-MB-468 cells was $<50 \%$ at $0.5 \mu \mathrm{M}$ doxorubicin, the viabilities of the MCF-7, MDA-MB-361, and MDA-MB-453 cells were $<50 \%$ at $1 \mu \mathrm{M}$ doxorubicin, the viabilities of the BT474, MDAMB-231, and MDA-MB-435 cells were $<50 \%$ at $5 \mu \mathrm{M}$ doxorubicin, and the viability of T47D cells was $<50 \%$ until the concentration of doxorubicin reached $10 \mu \mathrm{M}$. Among these breast cancer cell lines, the T47D cell line exhibited low sensitivity to doxorubicin, with a
IC50 value of $8.53 \mu \mathrm{M}$ (Fig. 1i). By contrast, the MDAMB-453 and MDA-MB-468 cells were more sensitive to doxorubicin than the T47D cells; they had lower $\mathrm{IC}_{50}$ values $(0.69$ and $0.27 \mu \mathrm{M}$, respectively) than the T47D cells and had the lowest viabilities at 5 and $10 \mu \mathrm{M}$ doxorubicin (Fig. 1g, h). Next, we analyzed whether sulbactam enhanced the cytotoxicity of doxorubicin in the breast cancer cells. When the cells were treated with a combination of sulbactam and doxorubicin, the viabilities of the eight breast cancer cell lines significantly decreased (Fig. 1b-i). The $\mathrm{IC}_{50}$ values of doxorubicin in all the cell lines in the presence and absence of sulbactam are summarized in Table 2 . The $\mathrm{IC}_{50}$ values of doxorubicin decreased from 1.14 to $0.54 \mu \mathrm{M}$ in the BT474 cells, from 0.69 to $0.37 \mu \mathrm{M}$ in the MCF-7 cells, from 3.16 to $1.25 \mu \mathrm{M}$ in the MDA-MB-231 cells, from 0.89 to $0.46 \mu \mathrm{M}$ in the MDA-MB-361 cells, from
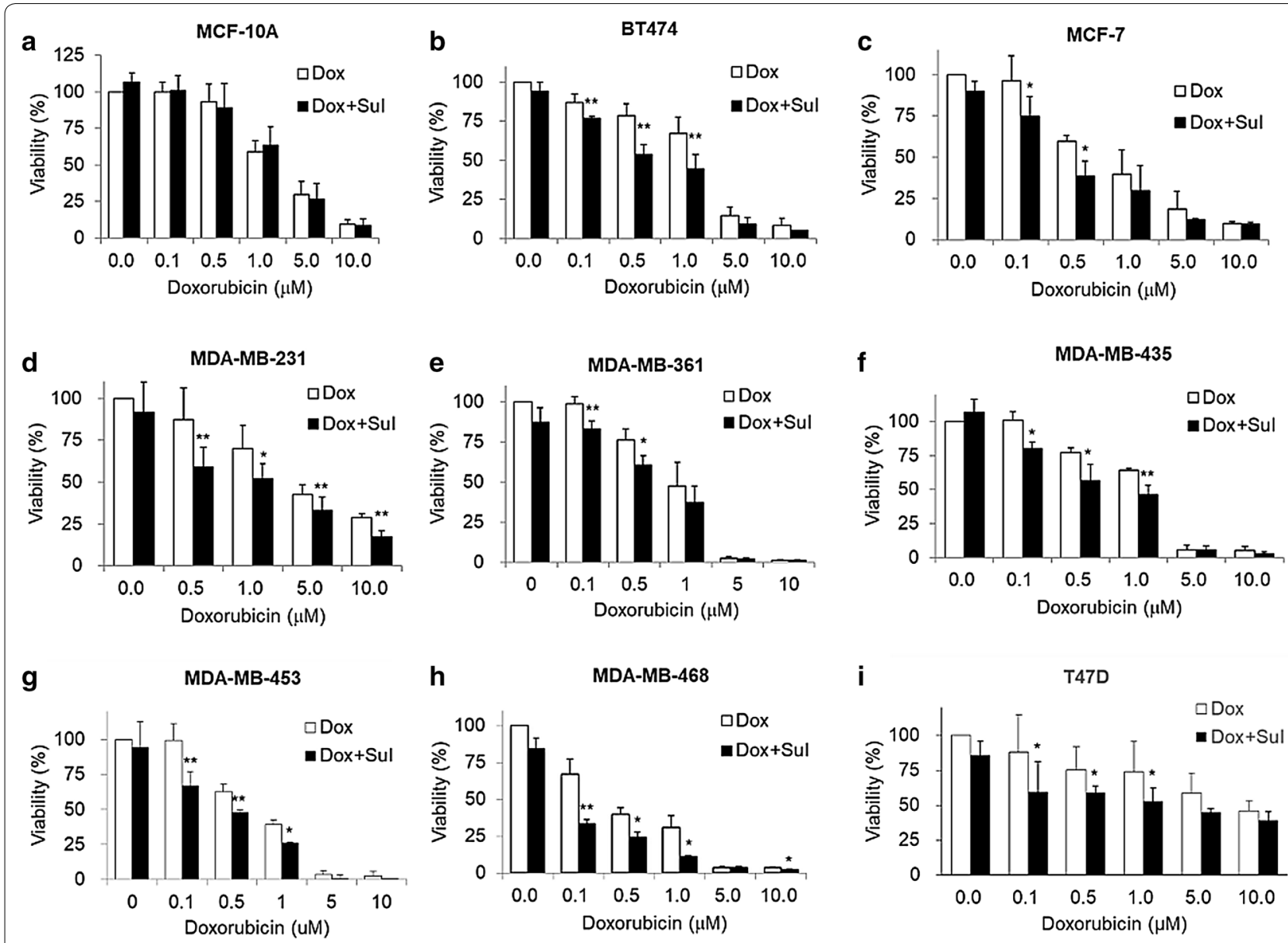

Fig. 1 Treatment with a combination of sulbactam and doxorubicin reduced the viability of breast cancer cells. a MCF10A, b BT474, c MCF-7, d MDA-MB-231, e MDA-MB-361, f MDA-MB-435, g MDA-MB-453, h MDA-MB-468, i T47D. Data are expressed as the percentage of cell viability compared with the negative control in which the cell viability was assumed to be $100 \%$. Reported values represent mean \pm SD of at least three independent experiments. ${ }^{*} \mathrm{p}<0.05$ and ${ }^{* *} \mathrm{p}<0.01$ versus only Dox-treated cells. Sul sulbactam, Dox doxorubicin, ER estrogen receptor, $P R$ progesterone receptor, HER2 human epidermal growth factor receptor 2, MTT 3-(4,5-dimethylthiazol-2-yl)-2,5-diphenyltetrazolium bromide, SD standard deviation 
Table $2 \mathrm{IC}_{50}$ and resistance fold of breast cell lines in the present of sulbactam and doxorubicin

\begin{tabular}{llll}
\hline Cell line & \multicolumn{2}{l}{$\begin{array}{l}\mathbf{I C}_{\mathbf{5 0}} \text { of Doxorubicin (Dox, } \\
\boldsymbol{n y y n}\end{array}$} & \multicolumn{2}{c}{ Resistance fold } \\
\cline { 2 - 3 } & Dox & Dox+Sul & Dox + Sul/Dox \\
\hline MCF10A & 2.51 & 2.50 & 1.00 \\
BT474 & 1.14 & 0.54 & 0.47 \\
MCF-7 & 0.69 & 0.37 & 0.54 \\
MDA-MB-231 & 3.16 & 1.25 & 0.40 \\
MDA-MB-361 & 0.89 & 0.46 & 0.51 \\
MDA-MB-435 & 1.22 & 0.51 & 0.42 \\
MDA-MB-453 & 0.69 & 0.27 & 0.39 \\
MDA-MB-468 & 0.27 & 0.05 & 0.20 \\
T47D & 8.53 & 3.83 & 0.45 \\
\hline
\end{tabular}

$\mathrm{IC}_{50}$ was calculated from the results of Fig. 1 using CompuSyn. Resistance fold was determined by dividing the IC50 values of cells treated with doxorubicin and $2 \mathrm{mM}$ sulbactam (Dox + Sul) by the IC50 of cells treated with doxorubicin (Dox)

1.22 to $0.51 \mu \mathrm{M}$ in the MDA-MB-435 cells, from 0.69 to $0.27 \mu \mathrm{M}$ in the MDA-MB-453 cells, from 0.27 to $0.05 \mu \mathrm{M}$ in the MDA-MB-468 cells, and from 8.53 to $3.83 \mu \mathrm{M}$ in the T47D cells in the presence of sulbactam. The $\mathrm{IC}_{50}$ of doxorubicin in breast cancer cells treated with a combination of sulbactam and doxorubicin was less than half of the $\mathrm{IC}_{50}$ of doxorubicin in the breast cancer cells treated with doxorubicin alone excluding the resistance of the MCF-7 and MDA-MB-361 cells, showed 1.85- and 1.96-fold decreases, respectively. By contrast, the MCF-10A cells (breast epithelial cells), did not exhibit evident differences in cell viability in the absence and presence of sulbactam; the $\mathrm{IC}_{50}$ values were 2.51 and 2.50, respectively (Fig. 1a). Among all the breast cancer cell lines, sulbactam considerably increased doxorubicin sensitivity in the MDA-MB-453 and MDA-MB-468 cells, by reducing the $\mathrm{IC}_{50}$ of doxorubicin by 2.6- and 5.0-fold, respectively, Subsequently, the cytotoxicity of sulbactam alone was analyzed in the
MCF-10A, MDA-MB-453, and MDA-MB-468 cells. The cells were treated with $0,1,2,4$, and $8 \mathrm{mM}$ sulbactam. Sulbactam did not exhibit an evident cytotoxic effect on any of the three cell lines at concentrations of up to $8 \mathrm{mM}$ (Fig. 2). However, when combined with $0.5 \mu \mathrm{M}$ doxorubicin, sulbactam potentiated the cytotoxicity of doxorubicin without evident dose dependence in the MDA-MB-453 and MDA-MB-468 cells. Thus, sulbactam has low cytotoxicity and can enhance the sensitivity of breast cancer cells toward doxorubicin.

\section{Proteomic profiling of total proteins from MDA-MB-468 cells treated with and without sulbactam in presence of doxorubicin}

The MDA-MB-468 cells were treated with or without $2 \mathrm{mM}$ sulbactam in the presence of $0.1 \mu \mathrm{M}$ doxorubicin for $24 \mathrm{~h}$. The total cell lysates were harvested for LC-MS/ MS analysis. In total, 2937 proteins were identified using Sequest, which were validated using Scaffold. The expression of 66 and 70 proteins were significantly upregulated and downregulated, respectively, in the MDA-MB-468 cells treated with a combination of sulbactam and doxorubicin (based on $\mathrm{p}$ value $<0.05$ and fold change $>2$; Tables 3 and 4). The UniProt database was used to classify the identified proteins according to their biological processes. The upregulated proteins were classified as RNA processing, response to DNA damage, response to stress, cytoskeleton organization, protein folding, ubiquitin-dependent protein catabolic process, vesicle-mediated transport, carbohydrate metabolism, amino acid metabolism, and positive regulation of apoptosis proteins (Table 3). The downregulated proteins were classified as translation, regulation of transcription, RNA processing, $\mathrm{ABC}$ transporter, cytoskeleton organization, protein folding, protein catabolic process, carbohydrate metabolism, mitochondrial metabolic process, negative regulation of apoptosis, and signal transduction proteins (Table 4). The connections among the proteins and GO biological

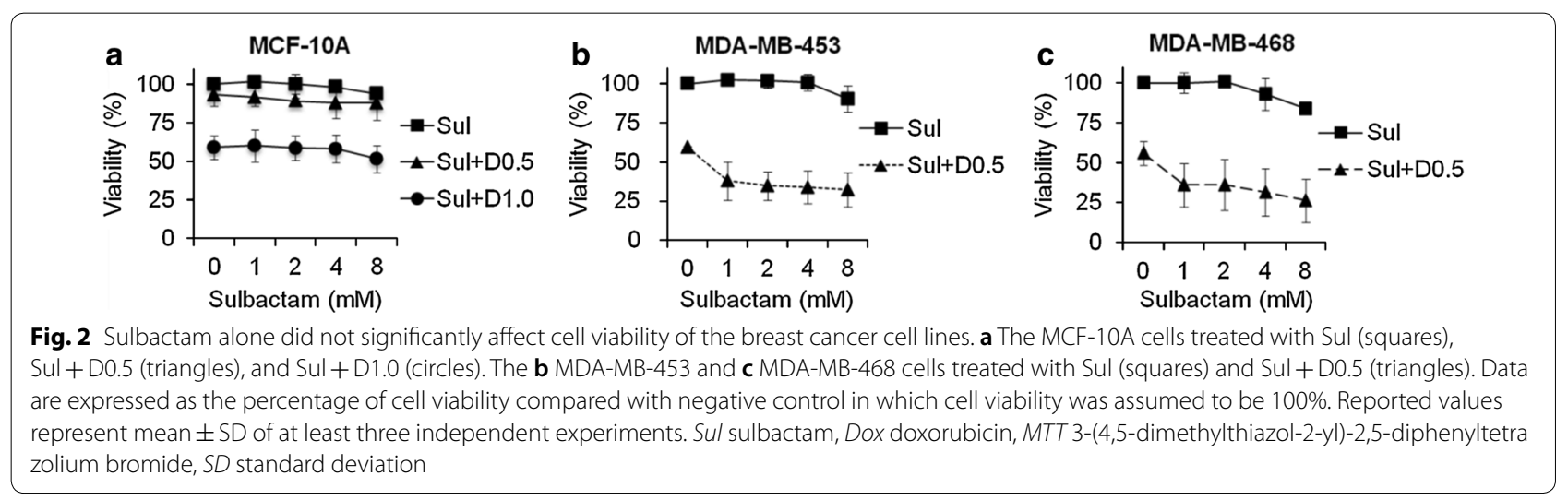


Table 3 List of upregulated proteins in the Dox- and Sul-treated MDA-MB-468 cells

\begin{tabular}{|c|c|c|c|c|c|c|c|c|c|}
\hline \multirow[t]{2}{*}{ Protein name } & \multirow[t]{2}{*}{ Abbreviation } & \multirow[t]{2}{*}{ UniProt ID } & \multirow[t]{2}{*}{ Mass (Da) } & \multirow[t]{2}{*}{ pl } & \multicolumn{2}{|c|}{ Spectrum count } & \multirow{2}{*}{$\begin{array}{l}\text { Dox + Sul/Dox } \\
\text { Fold }^{\mathrm{a}}\end{array}$} & \multirow[t]{2}{*}{$p$ value } & \multirow[t]{2}{*}{ Biological process } \\
\hline & & & & & Dox & Dox + Sul & & & \\
\hline $\begin{array}{l}\text { Putative pre-mRNA- } \\
\text { splicing factor } \\
\text { ATP-dependent RNA } \\
\text { helicase DHX15 }\end{array}$ & $\mathrm{DHX15}$ & 043143 & $90,932.8$ & 7.1 & 0.00 & 0.82 & 100.00 & $2.57 \mathrm{E}-07$ & RNA processing \\
\hline $\begin{array}{l}\text { U5 small nuclear } \\
\text { ribonucleoprotein } \\
200 \text { kDa helicase }\end{array}$ & SNRNP200 & 075643 & $244,507.6$ & 5.7 & 0.00 & 1.10 & 100.00 & $2.41 \mathrm{E}-02$ & RNA processing \\
\hline $\begin{array}{l}\text { Spliceosome RNA } \\
\text { helicase DDX39B }\end{array}$ & DDX39B & Q5STU3 & $48,826.1$ & 7.2 & 0.00 & 1.85 & 100.00 & $2.52 \mathrm{E}-05$ & RNA processing \\
\hline $\begin{array}{l}\text { ATP-dependent RNA } \\
\text { helicase DDX3X }\end{array}$ & DDX3X & O00571 & $73,112.2$ & 6.7 & 0.00 & 1.39 & 100.00 & $7.43 \mathrm{E}-04$ & RNA processing \\
\hline Nucleolar protein 14 & NOP14 & P78316 & $97,668.7$ & 9.1 & 0.00 & 0.96 & 100.00 & $1.50 \mathrm{E}-03$ & RNA processing \\
\hline $\begin{array}{l}\text { Growth arrest and DNA } \\
\text { damage-inducible } \\
\text { proteins-interacting } \\
\text { protein } 1\end{array}$ & GADD45GIP1 & Q8TAE8 & $25,383.9$ & 9.5 & 0.00 & 1.09 & 100.00 & 2.70E-02 & $\begin{array}{l}\text { Response to DNA } \\
\text { damage }\end{array}$ \\
\hline $\begin{array}{l}265 \text { protease regulatory } \\
\text { subunit } 6 \mathrm{~A}\end{array}$ & PSMC3 & P17980 & $49,203.5$ & 5.1 & 0.27 & 1.11 & 4.06 & $4.64 \mathrm{E}-02$ & $\begin{array}{l}\text { Response to DNA } \\
\text { damage }\end{array}$ \\
\hline $\begin{array}{l}\text { Proteasome subunit } \\
\text { beta type- } 4\end{array}$ & PSMB4 & P28070 & $29,204.3$ & 9.1 & 0.00 & 0.96 & 100.00 & $1.08 \mathrm{E}-03$ & $\begin{array}{l}\text { Response to DNA } \\
\text { damage }\end{array}$ \\
\hline $\begin{array}{l}\text { Transformation/tran- } \\
\text { scription domain- } \\
\text { associated protein }\end{array}$ & TRRAP & Q9Y4A5 & $437,601.8$ & 9.1 & 0.00 & 0.55 & 100.00 & $3.412 \mathrm{E}-05$ & $\begin{array}{l}\text { Response to DNA } \\
\text { damage }\end{array}$ \\
\hline Protein DEK & DEK & P35659 & $42,674.4$ & 9.3 & 0.00 & 1.53 & 100.00 & $6.37 \mathrm{E}-03$ & $\begin{array}{l}\text { Response to DNA } \\
\text { damage }\end{array}$ \\
\hline $\begin{array}{l}\text { Serine/threonine-pro- } \\
\text { tein kinase BRSK1 }\end{array}$ & BRSK1 & Q8TDC3 & $85,087.0$ & 9.5 & 0.00 & 0.55 & 100.00 & $2.57 \mathrm{E}-07$ & $\begin{array}{l}\text { Response to DNA } \\
\text { damage }\end{array}$ \\
\hline $\begin{array}{l}\text { Adenomatous polyposis } \\
\text { coli protein }\end{array}$ & APC & E7EMH9 & $32,790.8$ & 5.4 & 0.00 & 0.55 & 100.00 & $3.41 \mathrm{E}-05$ & $\begin{array}{l}\text { Response to DNA } \\
\text { damage }\end{array}$ \\
\hline $\begin{array}{l}\text { Dihydropyrimidinase- } \\
\text { related protein } 2\end{array}$ & DPYSL2 & Q16555 & $62,293.6$ & 5.9 & 0.00 & 0.98 & 100.00 & $1.32 \mathrm{E}-02$ & Response to stress \\
\hline $\begin{array}{l}\text { Sodium/potassium- } \\
\text { transporting ATPase } \\
\text { subunit beta-1 }\end{array}$ & ATP1B1 & P05026 & $35,061.3$ & 9.1 & 0.00 & 1.11 & 100.00 & $7.81 \mathrm{E}-03$ & Response to stress \\
\hline ERO1-like protein alpha & ERO1L & Q96HE7 & $51,991.8$ & 5.4 & 0.00 & 0.56 & 100.00 & $1.12 \mathrm{E}-04$ & Response to stress \\
\hline $\begin{array}{l}\text { STE20-like serine/threo- } \\
\text { nine-protein kinase }\end{array}$ & SLK & Q9H2G2 & $142,695.4$ & 3.7 & 0.00 & 0.70 & 100.00 & $2.30 \mathrm{E}-02$ & Response to stress \\
\hline $\begin{array}{l}\text { Heat shock-related } \\
70 \mathrm{kDa} \text { protein } 2\end{array}$ & HSPA2 & P54652 & $70,021.0$ & 5.6 & 0.00 & 2.69 & 100.00 & $9.41 \mathrm{E}-04$ & Response to stress \\
\hline $\begin{array}{l}\text { Putative heat shock } \\
70 \mathrm{kDa} \text { protein } 7\end{array}$ & HSPA6 & P48741 & $40,244.4$ & 7.7 & 0.00 & 3.08 & 100.00 & $5.50 E-03$ & Response to stress \\
\hline Lipoprotein, Lp(A) & LPA & Q1HP67 & $226,516.1$ & 7.2 & 0.00 & 0.55 & 100.00 & $2.57 \mathrm{E}-07$ & Response to stress \\
\hline Apolipoprotein(a) & LPA & P08519 & $501,319.8$ & 7.2 & 0.00 & 0.55 & 100.00 & $2.57 \mathrm{E}-07$ & Response to stress \\
\hline Peroxiredoxin-6 & PRDX6 & P30041 & $24,903.8$ & 6.0 & 0.27 & 1.68 & 6.15 & $1.42 \mathrm{E}-02$ & Response to stress \\
\hline $\begin{array}{l}\text { Solute carrier family } 12 \\
\text { member } 2\end{array}$ & $\mathrm{SLC} 12 \mathrm{~A} 2$ & P55011 & $131,447.1$ & 6.0 & 0.37 & 2.21 & 6.03 & $4.53 \mathrm{E}-03$ & Response to stress \\
\hline $\begin{array}{l}\text { Thioredoxin-related } \\
\text { transmembrane } \\
\text { protein } 1\end{array}$ & TMX1 & Q9H3N1 & $31,791.3$ & 3.7 & 0.00 & 0.83 & 100.00 & $2.70 \mathrm{E}-04$ & Response to stress \\
\hline $\begin{array}{l}\text { Transmembrane protein } \\
109\end{array}$ & TMEM109 & Q9BVC6 & $26,210.1$ & 11.2 & 0.00 & 0.56 & 100.00 & $2.70 \mathrm{E}-04$ & Response to stress \\
\hline $\begin{array}{l}\text { MICOS complex subunit } \\
\text { MIC60 }\end{array}$ & IMMT & Q16891 & $80,026.5$ & 5.7 & 1.12 & 2.74 & 2.45 & $1.34 \mathrm{E}-04$ & Response to stress \\
\hline $\begin{array}{l}\text { Signal transducer and } \\
\text { activator of transcrip- } \\
\text { tion }\end{array}$ & STAT1 & J3КРM9 & $83,360.6$ & 7.2 & 0.00 & 0.83 & 100.00 & $2.70 \mathrm{E}-04$ & Response to stress \\
\hline
\end{tabular}


Table 3 (continued)

\begin{tabular}{|c|c|c|c|c|c|c|c|c|c|}
\hline \multirow[t]{2}{*}{ Protein name } & \multirow[t]{2}{*}{ Abbreviation } & \multirow[t]{2}{*}{ UniProt ID } & \multirow[t]{2}{*}{ Mass (Da) } & \multirow[t]{2}{*}{ pl } & \multicolumn{2}{|c|}{ Spectrum count } & \multirow{2}{*}{$\begin{array}{l}\text { Dox + Sul/Dox } \\
\text { Fold }^{\mathrm{a}}\end{array}$} & \multirow[t]{2}{*}{$p$ value } & \multirow[t]{2}{*}{ Biological process } \\
\hline & & & & & Dox & Dox + Sul & & & \\
\hline CDNA FLJ78587 & TUBA1B & A8JZY9 & $50,135.7$ & 5.4 & 4.80 & 14.97 & 3.12 & $5.22 \mathrm{E}-03$ & $\begin{array}{l}\text { Cytoskeleton organi- } \\
\text { zation }\end{array}$ \\
\hline $\begin{array}{l}\text { Myosin regulatory light } \\
\text { chain } 12 \mathrm{~A}\end{array}$ & MYL12A & P19105 & $19,794.1$ & 4.7 & 1.23 & 5.81 & 4.71 & 3.07E-02 & $\begin{array}{l}\text { Cytoskeleton organi- } \\
\text { zation }\end{array}$ \\
\hline $\begin{array}{l}\text { Myosin regulatory light } \\
\text { chain } 12 \mathrm{~B}\end{array}$ & MYL12B & 014950 & $19,779.2$ & 4.7 & 1.23 & 5.81 & 4.71 & $3.07 E-02$ & $\begin{array}{l}\text { Cytoskeleton organi- } \\
\text { zation }\end{array}$ \\
\hline Actin-like protein 8 & ACTL8 & Q9H568 & $41,360.4$ & 7.2 & 0.27 & 1.11 & 4.06 & $4.64 \mathrm{E}-02$ & $\begin{array}{l}\text { Cytoskeleton organi- } \\
\text { zation }\end{array}$ \\
\hline Plastin-1 & PLS1 & Q14651 & $70,253.6$ & 5.4 & 0.00 & 0.97 & 100.00 & $7.05 E-03$ & $\begin{array}{l}\text { Cytoskeleton organi- } \\
\text { zation }\end{array}$ \\
\hline $\begin{array}{l}\text { F-actin-capping protein } \\
\text { subunit beta }\end{array}$ & CAPZB & P47756 & $31,219.3$ & 5.4 & 0.00 & 2.46 & 100.00 & $4.59 E-02$ & $\begin{array}{l}\text { Cytoskeleton organi- } \\
\text { zation }\end{array}$ \\
\hline Vimentin & VIM & BOYJC5 & $26,858.9$ & 3.7 & 0.00 & 0.69 & 100.00 & $2.03 E-02$ & $\begin{array}{l}\text { Cytoskeleton organi- } \\
\text { zation }\end{array}$ \\
\hline Filamin A & FLNA & Q60FE5 & $278,226.9$ & 7.2 & 2.51 & 7.53 & 3.01 & $2.05 E-02$ & $\begin{array}{l}\text { Cytoskeleton organi- } \\
\text { zation }\end{array}$ \\
\hline $\begin{array}{l}\text { Tubulin-folding cofac- } \\
\text { tor B }\end{array}$ & $\mathrm{TBCB}$ & Q99426 & $27,325.5$ & 8.7 & 0.00 & 0.70 & 100.00 & $2.30 E-02$ & $\begin{array}{l}\text { Cytoskeleton organi- } \\
\text { zation }\end{array}$ \\
\hline Tubulin beta-3 chain & TUBB3 & Q13509 & $50,432.7$ & 4.8 & 1.41 & 6.70 & 4.75 & $3.23 \mathrm{E}-02$ & $\begin{array}{l}\text { Cytoskeleton organi- } \\
\text { zation }\end{array}$ \\
\hline Tubulin beta-4A chain & TUBB4A & P04350 & $49,585.8$ & 4.8 & 0.00 & 1.94 & 100.00 & $2.70 \mathrm{E}-04$ & $\begin{array}{l}\text { Cytoskeleton organi- } \\
\text { zation }\end{array}$ \\
\hline $\begin{array}{l}\text { Kinesin heavy chain } \\
\text { isoform } 5 C\end{array}$ & KIF5C & O60282 & $109,494.8$ & 5.9 & 0.00 & 1.10 & 100.00 & $3.85 E-02$ & $\begin{array}{l}\text { Cytoskeleton organi- } \\
\text { zation }\end{array}$ \\
\hline Septin-9 & SEPTIN9 & Q9UHD8 & $65,401.6$ & 9.5 & 0.00 & 1.40 & 100.00 & $1.64 \mathrm{E}-02$ & $\begin{array}{l}\text { Cytoskeleton organi- } \\
\text { zation }\end{array}$ \\
\hline Laminin subunit alpha-2 & LAMA2 & A0A087WYF1 & $343,419.0$ & 7.2 & 0.28 & 1.26 & 4.46 & $4.32 \mathrm{E}-02$ & $\begin{array}{l}\text { Cytoskeleton organi- } \\
\text { zation }\end{array}$ \\
\hline Malectin & MLEC & Q14165 & $32,233.9$ & 7.2 & 0.00 & 0.70 & 100.00 & $2.15 \mathrm{E}-02$ & Protein folding \\
\hline $\begin{array}{l}\text { T-complex protein } 1 \\
\text { subunit gamma }\end{array}$ & ССТ3 & Q2TU64 & $60,579.1$ & 7.2 & 0.00 & 3.62 & 100.00 & $1.49 \mathrm{E}-02$ & Protein folding \\
\hline $\begin{array}{l}\text { Vesicle-associated } \\
\text { membrane protein- } \\
\text { associated protein B/C }\end{array}$ & VAPB & E5RK64 & 7801.0 & 9.5 & 0.00 & 1.54 & 100.00 & $3.83 \mathrm{E}-02$ & Protein folding \\
\hline $\begin{array}{l}\text { PEST proteolytic signal- } \\
\text { containing nuclear } \\
\text { protein }\end{array}$ & PCNP & Q8WW12 & $18,924.9$ & 6.9 & 0.28 & 1.91 & 6.95 & $2.46 \mathrm{E}-02$ & $\begin{array}{l}\text { Ubiquitin-dependent } \\
\text { protein catabolic } \\
\text { process }\end{array}$ \\
\hline $\begin{array}{l}\text { NEDD8-conjugating } \\
\text { enzyme Ubc12 }\end{array}$ & UBE2 M & P61081 & $20,900.0$ & 9.1 & 0.00 & 0.83 & 100.00 & $2.70 E-04$ & $\begin{array}{l}\text { Ubiquitin-dependent } \\
\text { protein catabolic } \\
\text { process }\end{array}$ \\
\hline Cullin-3 & CUL3 & A0A087WTG3 & $39,147.2$ & 9.5 & 0.00 & 1.94 & 100.00 & $2.70 \mathrm{E}-04$ & $\begin{array}{l}\text { Ubiquitin-dependent } \\
\text { protein catabolic } \\
\text { process }\end{array}$ \\
\hline Coatomer subunit beta & COPB1 & P53618 & $107,142.6$ & 7.2 & 0.00 & 1.10 & 100.00 & $3.02 \mathrm{E}-02$ & $\begin{array}{l}\text { Vesicle-mediated } \\
\text { transport }\end{array}$ \\
\hline $\begin{array}{l}\text { Endoplasmic reticulum } \\
\text { resident protein } 29\end{array}$ & ERP29 & F8VY02 & $18,115.9$ & 9.1 & 0.00 & 0.55 & 100.00 & $3.41 \mathrm{E}-05$ & $\begin{array}{l}\text { Vesicle-mediated } \\
\text { transport }\end{array}$ \\
\hline $\begin{array}{l}\text { Kinesin-like protein } \\
\text { KIF16B }\end{array}$ & KIF16B & Q96L93 & $152,011.7$ & 7.2 & 0.00 & 1.12 & 100.00 & $3.33 E-02$ & $\begin{array}{l}\text { Vesicle-mediated } \\
\text { transport }\end{array}$ \\
\hline $\begin{array}{l}\text { Phosphatidylinositol } \\
\text { N-acetylglucosaminyl- } \\
\text { transferase subunit A }\end{array}$ & PIGA & P37287 & $54,126.7$ & 9.1 & 0 & 0.55 & 100.00 & $2.574 \mathrm{E}-07$ & $\begin{array}{l}\text { Vesicle-mediated } \\
\text { transport }\end{array}$ \\
\hline $\begin{array}{l}\text { Ras-related protein } \\
\text { Rab-35 }\end{array}$ & RAB35 & Q15286 & $23,025.3$ & 9.1 & 0.00 & 0.98 & 100.00 & 8.01E-03 & $\begin{array}{l}\text { Vesicle-mediated } \\
\text { transport }\end{array}$ \\
\hline $\begin{array}{l}\text { Ras-related protein } \\
\text { Rab-15 }\end{array}$ & RAB15 & P59190 & $24,390.6$ & 5.5 & 0.00 & 0.98 & 100.00 & $8.01 E-03$ & $\begin{array}{l}\text { Vesicle-mediated } \\
\text { transport }\end{array}$ \\
\hline
\end{tabular}


Table 3 (continued)

\begin{tabular}{|c|c|c|c|c|c|c|c|c|c|}
\hline \multirow[t]{2}{*}{ Protein name } & \multirow[t]{2}{*}{ Abbreviation } & \multirow[t]{2}{*}{ UniProt ID } & \multirow[t]{2}{*}{ Mass (Da) } & \multirow[t]{2}{*}{ pl } & \multicolumn{2}{|c|}{ Spectrum count } & \multirow{2}{*}{$\begin{array}{l}\text { Dox+Sul/Dox } \\
\text { Fold }^{a}\end{array}$} & \multirow[t]{2}{*}{$p$ value } & \multirow[t]{2}{*}{ Biological process } \\
\hline & & & & & Dox & Dox+Sul & & & \\
\hline $\begin{array}{l}\text { Ras-related protein Rab- } \\
15 \text { isoform AN2 }\end{array}$ & RAB15 & G5ELZ5 & $13,781.8$ & 9.1 & 0.00 & 0.98 & 100.00 & $8.01 E-03$ & $\begin{array}{l}\text { Vesicle-mediated } \\
\text { transport }\end{array}$ \\
\hline $\begin{array}{l}\text { Ras-related protein Rab- } \\
15 \text { isoform AN3 }\end{array}$ & RAB15 & G5ELZ6 & $12,759.7$ & 9.1 & 0.00 & 0.98 & 100.00 & $8.01 \mathrm{E}-03$ & $\begin{array}{l}\text { Vesicle-mediated } \\
\text { transport }\end{array}$ \\
\hline Enolase & ENO1 & $\mathrm{F} 5 \mathrm{HOC} 8$ & $34,762.3$ & 3.6 & 0.00 & 0.83 & 100.00 & $2.70 E-04$ & $\begin{array}{l}\text { Carbohydrate metabo- } \\
\text { lism }\end{array}$ \\
\hline $\begin{array}{l}\text { Phosphoglycerate } \\
\text { mutase }\end{array}$ & PGAM1 & A4D2J6 & $28,219.6$ & 9.5 & 0.00 & 1.40 & 100.00 & $2.15 E-02$ & $\begin{array}{l}\text { Carbohydrate metabo- } \\
\text { lism }\end{array}$ \\
\hline $\begin{array}{l}\text { ATP-dependent 6-phos- } \\
\text { phofructokinase, } \\
\text { platelet type }\end{array}$ & PFKP & B1APP8 & $22,939.3$ & 9.1 & 0.00 & 0.56 & 100.00 & $1.12 \mathrm{E}-04$ & $\begin{array}{l}\text { Carbohydrate metabo- } \\
\text { lism }\end{array}$ \\
\hline Gamma-enolase & ENO2 & P09104 & $47,268.6$ & 4.9 & 0.00 & 0.83 & 100.00 & $2.70 E-04$ & $\begin{array}{l}\text { Carbohydrate metabo- } \\
\text { lism }\end{array}$ \\
\hline Transaldolase & TALDO1 & F2Z393 & $35,328.9$ & 9.5 & 0.00 & 2.75 & 100.00 & $3.85 E-02$ & $\begin{array}{l}\text { Carbohydrate metabo- } \\
\text { lism }\end{array}$ \\
\hline $\begin{array}{l}\text { Ganglioside-induced } \\
\text { differentiation-associ- } \\
\text { ated protein } 1\end{array}$ & GDAP1 & Q8TB36 & $41,345.8$ & 9.1 & 0.00 & 0.56 & 100.00 & $2.70 E-04$ & $\begin{array}{l}\text { Amino acid metabolic } \\
\text { process }\end{array}$ \\
\hline $\begin{array}{l}\text { Multifunctional meth- } \\
\text { yltransferase subunit } \\
\text { TRM112-like protein }\end{array}$ & TRMT112 & F5GX77 & $11,972.0$ & 7.8 & 0.00 & 0.56 & 100.00 & $1.12 \mathrm{E}-04$ & $\begin{array}{l}\text { Amino acid metabolic } \\
\text { process }\end{array}$ \\
\hline GCSH protein & GCSH & Q6IAT2 & $19,025.8$ & 3.7 & 0.00 & 0.96 & 100.00 & $8.84 \mathrm{E}-03$ & $\begin{array}{l}\text { Amino acid metabolic } \\
\text { process }\end{array}$ \\
\hline $\begin{array}{l}\text { Elongation factor } \\
1 \text {-alpha } 2\end{array}$ & EEF1A2 & Q05639 & $50,470.2$ & 9.1 & 0.00 & 3.21 & 100.00 & 1.94E-02 & $\begin{array}{l}\text { Positive regulation of } \\
\text { apoptotic process }\end{array}$ \\
\hline $\begin{array}{l}\text { Apoptotic chromatin } \\
\text { condensation inducer } \\
\text { in the nucleus }\end{array}$ & ACIN1 & Q9UKV3 & $151,861.9$ & 5.4 & 0.00 & 0.82 & 100.00 & $1.30 \mathrm{E}-02$ & $\begin{array}{l}\text { Positive regulation of } \\
\text { apoptotic process }\end{array}$ \\
\hline
\end{tabular}

Sul sulbactam, Dox doxorubicin

a The fold is from Dox + Sul/Dox, if the number of Dox is 0.00 , the fold would be shown as 100.00

processes of the proteins were tested through STRING network analysis. The proteins are represented as nodes. The thickness of the edges indicates the strength of correlations between the proteins according to neighborhood, gene fusion, co-occurrence, co-expression, previous experiments, databases, and text-mining information at confidence scores higher than 0.5. As shown in Fig. 3a, 38 of the 60 proteins which were upregulated in the MDAMB-468 cells treated with a combination of sulbactam and doxorubicin were associated with response to stimuli. Functional clusters included proteins involved in carbohydrate metabolism, tubulin-associated cytoskeleton organization, and ubiquitin-dependent protein catabolic process. As shown in Fig. 3b, 31 of 68 proteins which were downregulated in the MDA-MB-468 cells treated with a combination of sulbactam and doxorubicin were associated with gene expression. The functional clusters of these downregulated proteins were associated with actin remodeling, mitochondrial metabolic process, protein catabolic process, transcription and RNA process, and translation.

\section{Sulbactam downregulates mRNA levels of $A B C$ transporters in breast cancer cell lines}

Sulbactam significantly reduced ABC transporter protein expression in A. baumannii ATCC 19606. Breast cancer cells can actively remove doxorubicin from inside the cells by using $\mathrm{ABC}$ transporters to protect the cells from being killed by doxorubicin. LC-MS/ MS results showed a reduction in the protein levels of $A B C A 8, A B C B 1$, and $A B C G 2$; hence, we examined whether sulbactam can inhibit the mRNA expression of $\mathrm{ABC}$ transporters in the human breast cancer cells in the presence of doxorubicin. Two breast cancer cell lines, MDA-MB-453 and MDA-MB-468, were treated with $0.1 \mu \mathrm{M}$ doxorubicin and $2 \mathrm{mM}$ sulbactam for $24 \mathrm{~h}$. The mRNA expression of the ABC transporters in these two cell lines were measured using real-time RT-PCR. In the presence of doxorubicin, sulbactam significantly reduced the mRNA expression of ABCB1, $\mathrm{ABCB} 5$, and $\mathrm{ABCG} 2$ by approximately $50 \%$ in the MDA-MB-453 and MDA-MB-468 cells (Fig. 4). Sulbactam also moderately reduced the mRNA expression of 
Table 4 List of downregulated proteins in the Dox- and Sul-treated MDA-MB-468 cells

\begin{tabular}{|c|c|c|c|c|c|c|c|c|c|}
\hline \multirow[t]{2}{*}{ Protein name } & \multirow[t]{2}{*}{ Abbreviation } & \multirow[t]{2}{*}{ UniProt ID } & \multirow[t]{2}{*}{ Mass (Da) } & \multirow[t]{2}{*}{ pl } & \multicolumn{2}{|c|}{ Spectrum count } & \multirow{2}{*}{$\begin{array}{l}\text { Dox + sul/Dox } \\
\text { Fold }^{\mathrm{a}}\end{array}$} & \multirow[t]{2}{*}{$p$ value } & \multirow[t]{2}{*}{ Biological process } \\
\hline & & & & & Dox & Dox + Sul & & & \\
\hline $60 S$ ribosomal protein $L 4$ & RPL4 & P36578 & $47,566.1$ & 11.1 & 4.53 & 1.96 & -2.31 & $2.25 \mathrm{E}-02$ & Translation \\
\hline 60S ribosomal protein L17 & RPL17 & J3QLC8 & $20,246.8$ & 9.5 & 1.84 & 0.27 & -6.76 & $4.24 \mathrm{E}-02$ & Translation \\
\hline 60 S ribosomal protein L24 & RPL24 & C9JXB8 & $14,368.8$ & 11.3 & 0.56 & 0.00 & -100.00 & $1.30 \mathrm{E}-04$ & Translation \\
\hline $60 S$ ribosomal protein L27a & RPL27A & P46776 & $16,430.2$ & 11.0 & 3.20 & 1.47 & -2.17 & $1.42 \mathrm{E}-02$ & Translation \\
\hline $60 S$ ribosomal protein L37a & RPL37A & P61513 & $10,275.3$ & 9.5 & 1.39 & 0.00 & -100.00 & $4.08 \mathrm{E}-03$ & Translation \\
\hline 40S ribosomal protein S3a & RPS3A & D6RAT0 & $25,887.1$ & 9.5 & 7.51 & 0.00 & -100.00 & $4.01 E-03$ & Translation \\
\hline $\begin{array}{l}\text { Eukaryotic translation initiation } \\
\text { factor } 1 \mathrm{~A}, \mathrm{Y} \text {-chromosomal }\end{array}$ & EIF1AY & 014602 & $16,442.4$ & 4.6 & 0.65 & 0.00 & -100.00 & $1.43 \mathrm{E}-03$ & Translation \\
\hline $\begin{array}{l}\text { Eukaryotic translation initiation } \\
\text { factor } 1 \mathrm{~A}, \mathrm{X} \text {-chromosomal }\end{array}$ & EIF1AX & P47813 & $16,460.4$ & 4.6 & 0.65 & 0.00 & -100.00 & $1.43 E-03$ & Translation \\
\hline $\begin{array}{l}\text { Eukaryotic translation initiation } \\
\text { factor } 4 \text { gamma } 1\end{array}$ & $\mathrm{EIF} 4 \mathrm{G} 1$ & B2RU10 & $176,207.3$ & 5.4 & 1.12 & 0.00 & -100.00 & $3.18 \mathrm{E}-02$ & Translation \\
\hline $\begin{array}{l}\text { Eukaryotic translation initiation } \\
\text { factor } 3 \text { subunit J }\end{array}$ & EIF3 J & O75822 & $29,062.4$ & 3.7 & 1.38 & 0.27 & -5.10 & $1.16 \mathrm{E}-02$ & Translation \\
\hline $\begin{array}{l}\text { Eukaryotic translation initiation } \\
\text { factor } 6\end{array}$ & EIF6 & P56537 & $26,599.2$ & 3.7 & 0.70 & 0.00 & -100.00 & $2.17 \mathrm{E}-02$ & Translation \\
\hline $\begin{array}{l}\text { Nascent polypeptide-associ- } \\
\text { ated complex subunit alpha }\end{array}$ & NANA2 & Q13765 & $23,383.9$ & 4.5 & 1.57 & 0.00 & -100.00 & 1.47E-03 & Translation \\
\hline $\begin{array}{l}\text { Nascent polypeptide-associ- } \\
\text { ated complex subunit alpha, } \\
\text { muscle-specific form }\end{array}$ & NANA & F8VZJ2 & $15,016.0$ & 4.9 & 1.57 & 0.00 & -100.00 & $1.47 \mathrm{E}-03$ & Translation \\
\hline $\begin{array}{l}\text { Eukaryotic translation elonga- } \\
\text { tion factor } 1 \text { beta } 2\end{array}$ & EEF1B2 & A4D1M6 & $24,891.0$ & 3.7 & 1.26 & 0.00 & -100.00 & 7.44E-03 & Translation \\
\hline $\begin{array}{l}\text { Heterogeneous nuclear ribo- } \\
\text { nucleoprotein D0 }\end{array}$ & HNRNPD & Q14103 & $38,434.2$ & 7.6 & 4.25 & 2.39 & -1.78 & $2.07 \mathrm{E}-02$ & Translation \\
\hline $\begin{array}{l}\text { MAP kinase-interacting serine/ } \\
\text { threonine-protein kinase } 1\end{array}$ & MKNK1 & E9PMF1 & $12,586.3$ & 9.5 & 0.84 & 0.00 & -100.00 & $8.80 \mathrm{E}-07$ & Translation \\
\hline $\begin{array}{l}\text { Heterogeneous nuclear ribo- } \\
\text { nucleoproteins } \mathrm{C} 1 / \mathrm{C} 2\end{array}$ & HNPNPC & G3V2Q1 & $33,570.9$ & 5.0 & 3.50 & 0.81 & -4.30 & $2.30 \mathrm{E}-02$ & Translation \\
\hline $\begin{array}{l}\text { KH domain-containing, RNA- } \\
\text { binding, signal transduction- } \\
\text { associated protein } 1\end{array}$ & KHDRBS1 & Q07666 & $48,227.3$ & 8.7 & 0.97 & 0.00 & -100.00 & $1.21 \mathrm{E}-02$ & $\begin{array}{l}\text { Regulation of } \\
\text { transcription }\end{array}$ \\
\hline $\begin{array}{l}\text { High mobility group protein } \\
\text { HMG-I/HMG-Y }\end{array}$ & HMGA1 & P17096 & $11,544.8$ & 10.3 & 1.53 & 0.70 & -2.19 & $2.87 \mathrm{E}-02$ & $\begin{array}{l}\text { Regulation of } \\
\text { transcription }\end{array}$ \\
\hline $\begin{array}{l}\text { cDNA FLJ54188, moderately } \\
\text { similar to High mobility } \\
\text { group protein HMG-1/HMG-Y }\end{array}$ & HMGA1 & B4DWAO & $34,301.4$ & 10.4 & 1.53 & 0.70 & -2.19 & $2.87 \mathrm{E}-02$ & $\begin{array}{l}\text { Regulation of } \\
\text { transcription }\end{array}$ \\
\hline $\begin{array}{l}\text { Serrate RNA effector molecule } \\
\text { homolog }\end{array}$ & SRRT & Q9BXP5 & $100,666.7$ & 7.2 & 0.97 & 0.00 & -100.00 & $7.88 \mathrm{E}-03$ & $\begin{array}{l}\text { Regulation of } \\
\text { transcription }\end{array}$ \\
\hline Protein SIX6OS1 & C14orf39 & Q8N1H7 & $68,166.0$ & 5.4 & 0.56 & 0.00 & -100.00 & $1.30 \mathrm{E}-04$ & $\begin{array}{l}\text { Regulation of } \\
\text { transcription }\end{array}$ \\
\hline $\begin{array}{l}\text { Heterogeneous nuclear ribo- } \\
\text { nucleoprotein D-like }\end{array}$ & HNRPDL & 014979 & $46,437.5$ & 9.6 & 2.23 & 0.00 & -100.00 & $9.63 \mathrm{E}-03$ & $\begin{array}{l}\text { Regulation of } \\
\text { transcription }\end{array}$ \\
\hline $\begin{array}{l}\text { Zinc finger and BTB domain- } \\
\text { containing protein } 14\end{array}$ & ZFP161 & O43829 & $50,956.5$ & 5.4 & 0.74 & 0.00 & -100.00 & $9.26 \mathrm{E}-03$ & $\begin{array}{l}\text { Regulation of } \\
\text { transcription }\end{array}$ \\
\hline Golgin-45 & BLZF1 & Q9H2G9 & $44,910.4$ & 9.1 & 0.70 & 0.00 & -100.00 & $1.68 \mathrm{E}-02$ & $\begin{array}{l}\text { Regulation of } \\
\text { transcription }\end{array}$ \\
\hline Zinc finger protein neuro-d4 & DPF1 & E9PDV3 & $45,285.6$ & 7.2 & 0.56 & 0.00 & -100.00 & $1.30 \mathrm{E}-04$ & $\begin{array}{l}\text { Regulation of } \\
\text { transcription }\end{array}$ \\
\hline Histone cluster 1, H1e & HIST1H1E & Q4VB24 & $21,893.3$ & 9.5 & 4.44 & 0.00 & -100.00 & $1.25 \mathrm{E}-02$ & $\begin{array}{l}\text { Regulation of } \\
\text { transcription }\end{array}$ \\
\hline $\begin{array}{l}\text { Serine/arginine-rich splicing } \\
\text { factor } 10\end{array}$ & SRSF10 & O75494 & $31,300.5$ & 11.2 & 0.56 & 0.00 & -100.00 & 1.30E-04 & RNA processing \\
\hline $\begin{array}{l}\text { Heterogeneous nuclear ribo- } \\
\text { nucleoprotein Q }\end{array}$ & SYNCRIP & O60506 & $69,471.4$ & 8.7 & 5.98 & 1.95 & -3.07 & $3.52 \mathrm{E}-02$ & RNA processing \\
\hline
\end{tabular}


Table 4 (continued)

\begin{tabular}{|c|c|c|c|c|c|c|c|c|c|}
\hline \multirow[t]{2}{*}{ Protein name } & \multirow[t]{2}{*}{ Abbreviation } & \multirow[t]{2}{*}{ UniProt ID } & \multirow[t]{2}{*}{ Mass (Da) } & \multirow[t]{2}{*}{$\mathrm{pl}$} & \multicolumn{2}{|c|}{ Spectrum count } & \multirow{2}{*}{$\begin{array}{l}\text { Dox + sul/Dox } \\
\text { Fold }^{a}\end{array}$} & \multirow[t]{2}{*}{$p$ value } & \multirow[t]{2}{*}{ Biological process } \\
\hline & & & & & Dox & Dox + Sul & & & \\
\hline $\begin{array}{l}\text { Transformer-2 protein } \\
\text { homolog alpha }\end{array}$ & TRA2A & Q13595 & $32,688.6$ & 11.2 & 1.11 & 0.18 & -6.02 & $3.23 \mathrm{E}-02$ & RNA processing \\
\hline Multidrug resistance protein 1 & $\mathrm{ABCB} 1$ & P08183 & $141,479.1$ & 9.1 & 3.47 & 0.84 & -4.13 & $5.08 \mathrm{E}-04$ & Transporters \\
\hline $\begin{array}{l}\text { ATP-binding cassette sub- } \\
\text { family G member } 2\end{array}$ & $\mathrm{ABCG} 2$ & Q9UNQ0 & $72,314.0$ & 8.9 & 1.66 & 0.36 & -4.56 & $1.05 E-03$ & Transporters \\
\hline $\begin{array}{l}\text { ATP-binding cassette sub- } \\
\text { family A member } 8\end{array}$ & ABCA8 & O94911 & $179,245.9$ & 9.1 & 0.56 & 0.00 & -100.00 & $8.80 \mathrm{E}-07$ & Transporters \\
\hline $\begin{array}{l}\text { Sodium/potassium-transport- } \\
\text { ing ATPase subunit alpha-4 }\end{array}$ & ATP1A4 & E9PRA5 & $57,244.4$ & 9.1 & 0.56 & 0.00 & -100.00 & $1.30 \mathrm{E}-04$ & Transporters \\
\hline Syntaxin-8 & STX8 & Q9UNKO & $26,906.8$ & 3.7 & 0.56 & 0.00 & -100.00 & $8.80 \mathrm{E}-07$ & Transporters \\
\hline $\begin{array}{l}\text { Wiskott-Aldrich syndrome } \\
\text { protein family member } 1\end{array}$ & WASF1 & Q92558 & $61,652.4$ & 5.4 & 0.56 & 0.00 & -100.00 & $1.30 \mathrm{E}-04$ & $\begin{array}{l}\text { Cytoskeleton } \\
\text { organization }\end{array}$ \\
\hline $\begin{array}{l}\text { Actin-related protein } 2 / 3 \\
\text { complex subunit } 2\end{array}$ & ARPC2 & 015144 & $34,333.1$ & 9.1 & 1.23 & 0.00 & -100.00 & $5.68 \mathrm{E}-03$ & $\begin{array}{l}\text { Cytoskeleton } \\
\text { organization }\end{array}$ \\
\hline $\begin{array}{l}\text { Actin-related protein 2/3 } \\
\text { complex subunit } 3\end{array}$ & ARPC3 & 015145 & $20,415.5$ & 8.8 & 0.97 & 0.00 & -100.00 & $7.88 \mathrm{E}-03$ & $\begin{array}{l}\text { Cytoskeleton } \\
\text { organization }\end{array}$ \\
\hline $\begin{array}{l}\text { Ras GTPase-activating-like } \\
\text { protein IQGAP1 }\end{array}$ & IQGAP1 & P46940 & $189,120.8$ & 6.1 & 1.25 & 0.00 & -100.00 & $4.32 \mathrm{E}-04$ & $\begin{array}{l}\text { Cytoskeleton } \\
\text { organization }\end{array}$ \\
\hline Myosin light chain 6B & MYL6B & P14649 & 22764.1 & 6.3 & 2.23 & 0.00 & -100.00 & $8.80 \mathrm{E}-07$ & $\begin{array}{l}\text { Cytoskeleton } \\
\text { organization }\end{array}$ \\
\hline $\begin{array}{l}\text { TBC1 domain family member } \\
31\end{array}$ & WDR67 & Q96DN5 & 124189.8 & 9.1 & 1.11 & 0.00 & -100.00 & $9.75 E-04$ & $\begin{array}{l}\text { Cytoskeleton } \\
\text { organization }\end{array}$ \\
\hline Prelamin-A/C & LMNA & Q5TCl8 & 55762.4 & 6.6 & 10.73 & 0.28 & -37.73 & $1.74 \mathrm{E}-02$ & $\begin{array}{l}\text { Cytoskeleton } \\
\text { organization }\end{array}$ \\
\hline Lamin A/C & LMNA & W8QEH3 & 65116.9 & 9.1 & 11.69 & 0.00 & -100.00 & $8.86 \mathrm{E}-03$ & $\begin{array}{l}\text { Cytoskeleton } \\
\text { organization }\end{array}$ \\
\hline Calumenin & CALU & O43852 & 34961.1 & 4.5 & 1.66 & 0.36 & -4.60 & $2.73 E-02$ & $\begin{array}{l}\text { Cytoskeleton } \\
\text { organization }\end{array}$ \\
\hline $\begin{array}{l}\text { Lamina-associated polypep- } \\
\text { tide } 2 \text {, isoforms beta/gamma }\end{array}$ & TMPO & P42167 & 50670.3 & 9.5 & 1.85 & 0.74 & -2.49 & $2.75 E-02$ & $\begin{array}{l}\text { Cytoskeleton } \\
\text { organization }\end{array}$ \\
\hline Kinesin-like protein & KIF15 & A0A087X0P0 & 312105.2 & 5.5 & 2.19 & 0.00 & -100.00 & $6.76 \mathrm{E}-06$ & $\begin{array}{l}\text { Cytoskeleton } \\
\text { organization }\end{array}$ \\
\hline $\begin{array}{l}\text { DnaJ homolog subfamily A } \\
\text { member } 1\end{array}$ & DNAJA1 & P31689 & 44868.4 & 7.2 & 1.26 & 0.36 & -3.44 & $2.12 \mathrm{E}-02$ & Protein folding \\
\hline $\begin{array}{l}\text { T-complex protein } 1 \text { subunit } \\
\text { epsilon }\end{array}$ & CCT5 & P48643 & 59539.8 & 5.4 & 3.47 & 0.41 & -8.39 & $9.26 \mathrm{E}-03$ & Protein folding \\
\hline $\begin{array}{l}\text { T-complex protein } 1 \text { subunit } \\
\text { beta }\end{array}$ & ССТ2 & P78371 & 57357.0 & 6.0 & 1.11 & 0.00 & -100.00 & $1.30 \mathrm{E}-04$ & Protein folding \\
\hline $\begin{array}{l}\text { Cysteine and histidine-rich } \\
\text { domain-containing protein } 1\end{array}$ & CHORDC1 & Q9UHD1 & 37489.9 & 7.2 & 0.55 & 0.00 & -100.00 & $6.76 \mathrm{E}-06$ & Protein folding \\
\hline CDC37 protein & CDC37 & Q6FG59 & 44453.5 & 3.7 & 1.78 & 0.41 & -4.38 & $4.29 \mathrm{E}-02$ & Protein folding \\
\hline $\begin{array}{l}26 S \text { proteasome non-ATPase } \\
\text { regulatory subunit } 7\end{array}$ & PSMD7 & P51665 & 37025.4 & 6.3 & 0.69 & 0.00 & -100.00 & $1.95 \mathrm{E}-02$ & $\begin{array}{l}\text { Protein catabolic } \\
\text { process }\end{array}$ \\
\hline $\begin{array}{l}\text { Proteasome subunit beta } \\
\text { type-3 }\end{array}$ & PSMB3 & P49720 & 22949.0 & 9.1 & 0.56 & 0.00 & -100.00 & $1.30 \mathrm{E}-04$ & $\begin{array}{l}\text { Protein catabolic } \\
\text { process }\end{array}$ \\
\hline $\begin{array}{l}\text { Proteasome subunit alpha } \\
\text { type- } 4\end{array}$ & PSMA4 & P25789 & 29483.8 & 7.6 & 0.65 & 0.00 & -100.00 & $1.01 \mathrm{E}-03$ & $\begin{array}{l}\text { Protein catabolic } \\
\text { process }\end{array}$ \\
\hline $\begin{array}{l}\text { Ubiquitin carboxyl-terminal } \\
\text { hydrolase } 43\end{array}$ & USP43 & Q70EL4 & 122809.5 & 9.5 & 0.83 & 0.00 & -100.00 & 4.42E-02 & $\begin{array}{l}\text { Protein catabolic } \\
\text { process }\end{array}$ \\
\hline Enolase-like protein ENO4 & ENO4 & J3KNX1 & 68464.9 & 6.3 & 1.11 & 0.00 & -100.00 & $5.54 \mathrm{E}-03$ & $\begin{array}{l}\text { Carbohydrate } \\
\text { metabolism }\end{array}$ \\
\hline PCK2 protein & PCK2 & Q6IB91 & 70697.2 & 7.2 & 0.70 & 0.00 & -100.00 & $2.17 \mathrm{E}-02$ & $\begin{array}{l}\text { Carbohydrate } \\
\text { metabolism }\end{array}$ \\
\hline $\begin{array}{l}\text { Fructose-bisphosphate } \\
\text { aldolase }\end{array}$ & ALDOC & A8MVZ9 & 36295.3 & 7.6 & 1.53 & 0.00 & -100.00 & $2.78 \mathrm{E}-03$ & $\begin{array}{r}\text { Carbohydrate } \\
\text { metabolism }\end{array}$ \\
\hline
\end{tabular}


Table 4 (continued)

\begin{tabular}{|c|c|c|c|c|c|c|c|c|c|}
\hline \multirow[t]{2}{*}{ Protein name } & \multirow[t]{2}{*}{ Abbreviation } & \multirow[t]{2}{*}{ UniProt ID } & \multirow[t]{2}{*}{ Mass (Da) } & \multirow[t]{2}{*}{$\mathrm{pl}$} & \multicolumn{2}{|c|}{ Spectrum count } & \multirow{2}{*}{$\begin{array}{l}\text { Dox + sul/Dox } \\
\text { Fold }^{\mathrm{a}}\end{array}$} & \multirow[t]{2}{*}{$p$ value } & \multirow[t]{2}{*}{ Biological process } \\
\hline & & & & & Dox & Dox + Sul & & & \\
\hline $\begin{array}{l}\text { Cytochrome c oxidase subunit } \\
5 \mathrm{~A} \text {, mitochondrial }\end{array}$ & $\operatorname{cox} 5 \mathrm{~A}$ & H3BNX8 & 17234.9 & 7.2 & 1.24 & 0.00 & -100.00 & $4.42 \mathrm{E}-02$ & $\begin{array}{l}\text { Mitochondrial met- } \\
\text { abolic process }\end{array}$ \\
\hline Cytochrome b5 type B & CYB5B & J3KNF8 & 16694.6 & 6.3 & 0.82 & 0.00 & -100.00 & 4.69E-02 & $\begin{array}{l}\text { Mitochondrial met- } \\
\text { abolic process }\end{array}$ \\
\hline $\begin{array}{l}\text { Cytochrome b-c1 complex } \\
\text { subunit } 1 \text {, mitochondrial }\end{array}$ & UQCRC1 & P31930 & 52646.0 & 7.2 & 0.56 & 0.00 & -100.00 & $1.30 E-04$ & $\begin{array}{l}\text { Mitochondrial met- } \\
\text { abolic process }\end{array}$ \\
\hline MICOS complex subunit MIC19 & $\mathrm{CHCHD} 3$ & Q9NX63 & 26152.4 & 9.1 & 0.70 & 0.00 & -100.00 & 1.68E-02 & $\begin{array}{l}\text { Mitochondrial met- } \\
\text { abolic process }\end{array}$ \\
\hline $\begin{array}{l}\text { Phosphoenolpyruvate carbox- } \\
\text { ykinase [GTP], mitochondrial }\end{array}$ & PCK2 & Q16822 & 70730.2 & 7.2 & 0.70 & 0.00 & -100.00 & $2.17 E-02$ & $\begin{array}{l}\text { Mitochondrial met- } \\
\text { abolic process }\end{array}$ \\
\hline $\begin{array}{l}\text { Dihydrolipoyllysine-residue } \\
\text { succinyltransferase com- } \\
\text { ponent of 2-oxoglutarate } \\
\text { dehydrogenase complex, } \\
\text { mitochondrial }\end{array}$ & DLST & P36957 & 48755.5 & 9.5 & 0.56 & 0.00 & -100.00 & $1.30 E-04$ & $\begin{array}{l}\text { Mitochondrial met- } \\
\text { abolic process }\end{array}$ \\
\hline $\begin{array}{l}\text { Pyruvate dehydrogenase E1 } \\
\text { component subunit alpha, } \\
\text { somatic form, mitochondrial }\end{array}$ & PDHA1 & P08559 & 43295.8 & 9.1 & 0.56 & 0.00 & -100.00 & 1.30E-04 & $\begin{array}{l}\text { Mitochondrial met- } \\
\text { abolic process }\end{array}$ \\
\hline Apoptosis inhibitor 5 & API5 & Q9BZZ5 & 59004.7 & 9.1 & 1.21 & 0.27 & -4.44 & 4.79E-02 & $\begin{array}{l}\text { Negative regula- } \\
\text { tion of apoptotic } \\
\text { process }\end{array}$ \\
\hline $\begin{array}{l}\text { Epidermal growth factor } \\
\text { receptor }\end{array}$ & EGFR & A9CB80 & 132022.7 & 6.2 & 6.03 & 0.54 & -11.12 & $5.65 \mathrm{E}-03$ & Signal transduction \\
\hline A-kinase anchor protein 9 & AKAP9 & Q99996 & 453668.7 & 3.7 & 0.84 & 0.00 & -100.00 & $7.75 \mathrm{E}-05$ & Signal transduction \\
\hline $\begin{array}{l}\text { Rho GDP-dissociation inhibi- } \\
\text { tor } 1\end{array}$ & ARHGDIA & J3KS60 & 9944.0 & 4.2 & 0.65 & 0.00 & -100.00 & $5.33 \mathrm{E}-03$ & Signal transduction \\
\hline $\begin{array}{l}\text { Serine/threonine-protein } \\
\text { phosphatase PP1-alpha } \\
\text { catalytic subunit }\end{array}$ & PPP1CA & P62136 & 37512.2 & 7.2 & 1.81 & 0.00 & -100.00 & $4.26 \mathrm{E}-03$ & Signal transduction \\
\hline
\end{tabular}

Sul sulbactam, Dox doxorubicin

a The fold is from Dox/Dox + Sul, and "-" means the expression of protein was decrease in Dox + Sul group. If the number of Dox + Sul is 0.00 , the fold would be shown as -100.00

$\mathrm{ABCB} 8, \mathrm{ABCB} 10, \mathrm{ABCC} 1, \mathrm{ABCC} 2, \mathrm{ABCC} 3, \mathrm{ABCC} 4$, and $A B C C 5$ in the MDA-MB-453 cells and those of $\mathrm{ABCB} 8, \mathrm{ABCB} 10, \mathrm{ABCC} 2, \mathrm{ABCC} 5$, and $\mathrm{ABCC} 10$ in the MDA-MB-468 cells by $20-30 \%$. These results indicate that sulbactam downregulated the mRNA expression of several ABC transporters, particularly ABCB1, ABCB5, and $A B C G 2$. These results also demonstrate that the combination of sulbactam and doxorubicin enhanced the sensitivity of the cells to doxorubicin by downregulating the expressions of $\mathrm{ABC}$ transporters related to the efflux of doxorubicin.

\section{Sulbactam prolongs doxorubicin retention in breast cancer cells}

To investigate whether the sulbactam-induced reduction in the expression of $\mathrm{ABC}$ transporters inhibits the efflux of doxorubicin, the distribution of doxorubicin in breast cancer cells was observed using a confocal microscope. A time-course study was performed in the presence and absence of sulbactam. For comparison, the cells were also pretreated with verapamil, a wellknown inhibitor of ABCB1 and ABCG2. The fluorescent signal corresponding to doxorubicin was primarily observed in nuclei of the cells, and the concentration

(See figure on next page.)

Fig. 3 Differentially expressed proteins in the MDA-MB-468 cells in the presence of sulbactam and doxorubicin. Proteins are represented as nodes. a Upregulated proteins in the Dox/Sul-treated MDA-MB-468 cells. Red nodes indicate proteins that are related to the response to stimulus. b Downregulated proteins in the Dox/Sul-treated MDA-MB-468 cells. Red nodes indicate the proteins that are related to gene expression. Sul sulbactam, Dox doxorubicin 


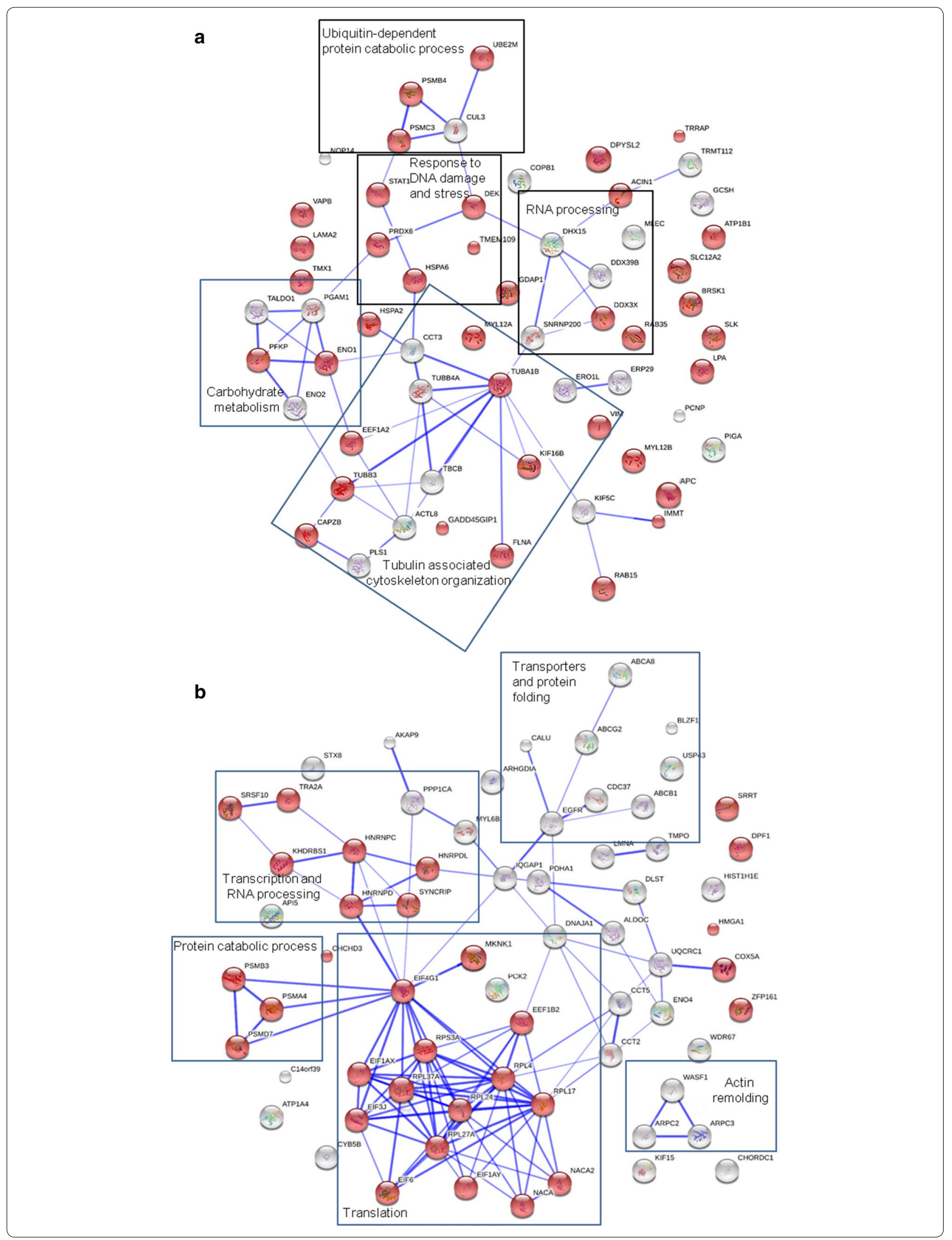


of doxorubicin decreased time-dependently (Fig. 5). Pretreatment with sulbactam increased the doxorubicin concentration in the cell nuclei by 15,45 , and $74 \%$ in the MDA-MB-453 cells and 17,26 , and $44 \%$ in the MDA-MB- 468 cells at 8,12 , and $16 \mathrm{~h}$, respectively, compared with that in cells without sulbactam treatment. The intensities of doxorubicin were comparable between the sulbactam- and verapamil-treated MDAMB-453 cells. Doxorubicin concentration was higher in the sulbactam-treated MDA-MB-468 cells than in the verapamil-treated cells. These results indicate that sulbactam inhibited the efflux of doxorubicin, thus prolonging doxorubicin retention in the breast cancer cells. The increase in intracellular doxorubicin levels resulted in an increase in its cytotoxicity in the breast cancer cells.

\section{Discussion}

The coadministration of sulbactam and a $\beta$-lactam antibiotic, such as ampicillin, is an effective therapy against bacteria, such as A. baumannii [42]. Sulbactam alone has intrinsic bactericidal effects against multidrug-resistant A. baumannii because it inhibits the expression of the $\mathrm{ABC}$ transporters as well as that of $30 \mathrm{~S}$ and $50 \mathrm{~S}$ ribosomal subunit proteins [38]. However, the effects of sulbactam have not been explored in mammalian cells, thus far. Our study results suggest that sulbactam enhanced the cytotoxicity of doxorubicin in many of the tested breast cancer cell lines. Because of the high heterogeneity of breast cancer, we classified breast cancer cell lines as hormone-receptor-positive cancer, HER2-positive cancer, and TNBC; the cells were then treated with sulbactam and doxorubicin. All the cell lines responded to doxorubicin and sulbactam-a finding is evidently uncorrelated with the characteristic of these cell lines. Thus, a combination of doxorubicin and sulbactam exhibited the most significant cytotoxicity in the MDA-MB-453 and MDA-MB-468 cells. Dose-dependency tests showed that approximately 1-8 $\mathrm{mM}$ sulbactam was not cytotoxic to MDA-MB-453, MDA-MB-468, and MCF10A cells, which are typically used as normal breast cell lines; hence, in combination with doxorubicin, sulbactam exerted a synergistic effect on doxorubicin.

The results of LC-MS/MS indicated that most of the upregulated proteins (21/66) associated with stress and DNA damage response, such as heat shock-related $70-\mathrm{kDa}$ protein 2 and adenomatous polyposis coli protein, may respond to the stress caused by sulbactam. When used as a drug, sulbactam also stimulates some metabolic pathways and cytoskeleton organizations, such as carbohydrate metabolism and tubulin-associated cytoskeleton organization. In the presence of doxorubicin and sulbactam evidently inhibited the initiation of

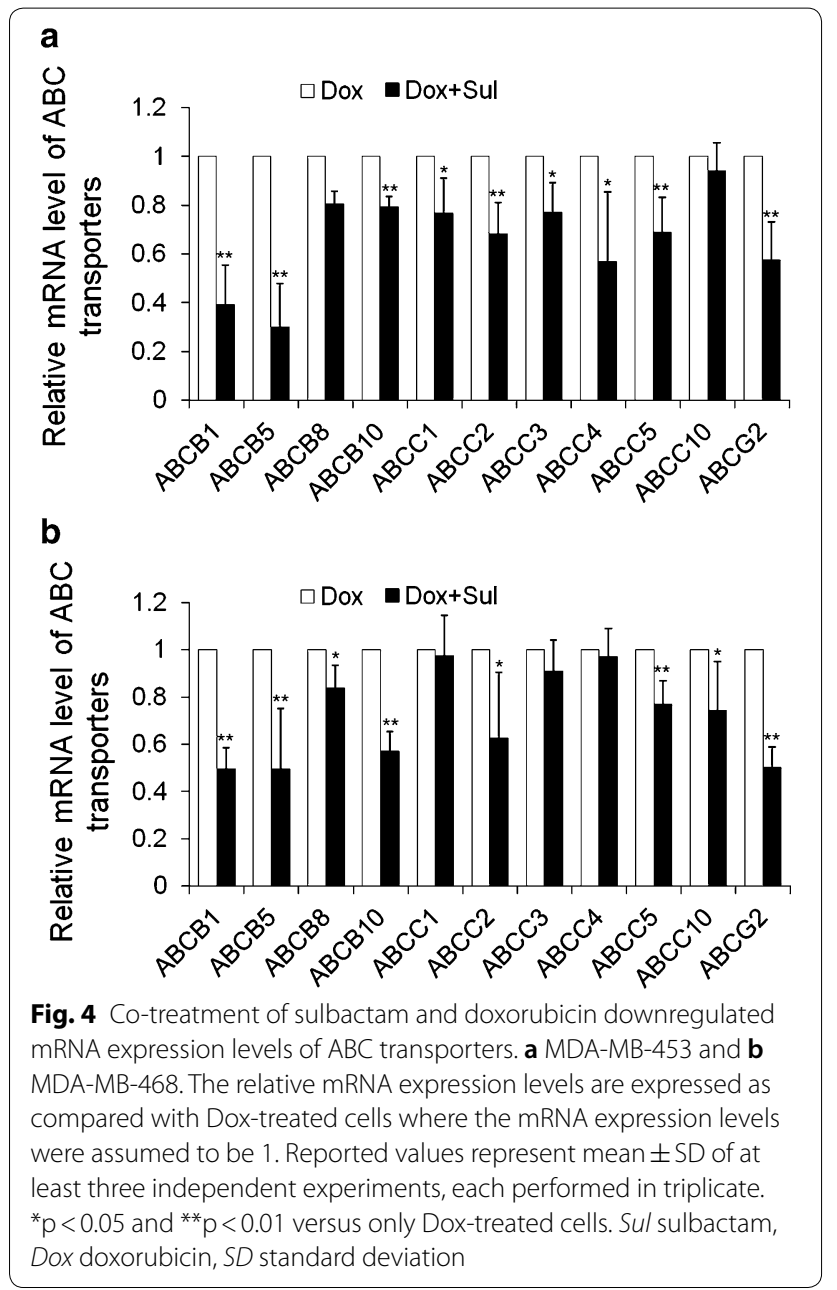

RNA processing, transcription, and translation (Fig. 6). Doxorubicin interacts with DNA through intercalation between bases and macromolecular biosynthesis inhibition [19]. This inhibits the progression of topoisomerase II, which relaxes supercoils in DNA during transcription. Through intercalation, doxorubicin can also induce histone eviction from transcriptionally active chromatin [43]. Consequently, here, RNA processing and translation were downregulated in the doxorubicin-exposed cells. Sulbactam increased the doxorubicin retention time in the breast cancer cells. Therefore, in the presence of sulbactam, the effects of doxorubicin on transcription and translation were enhanced, and the $60 \mathrm{~S}$ ribosomal proteins, namely L4, L17, L24, L37a, and 40S ribosomal protein $3 \mathrm{~A}$, and translation initiation-associated proteins, namely eIF1A, eIF3, eIF4G1, eIF6, and eEF1B, were downregulated. Hence, the initiation of the translation pathway was inhibited (Fig. 6). The results of LC-MS/MS also indicated that the expression of $A B C$ transporter proteins $\mathrm{ABCA} 8, \mathrm{ABCB} 1$, and $\mathrm{ABCG} 2$ were 


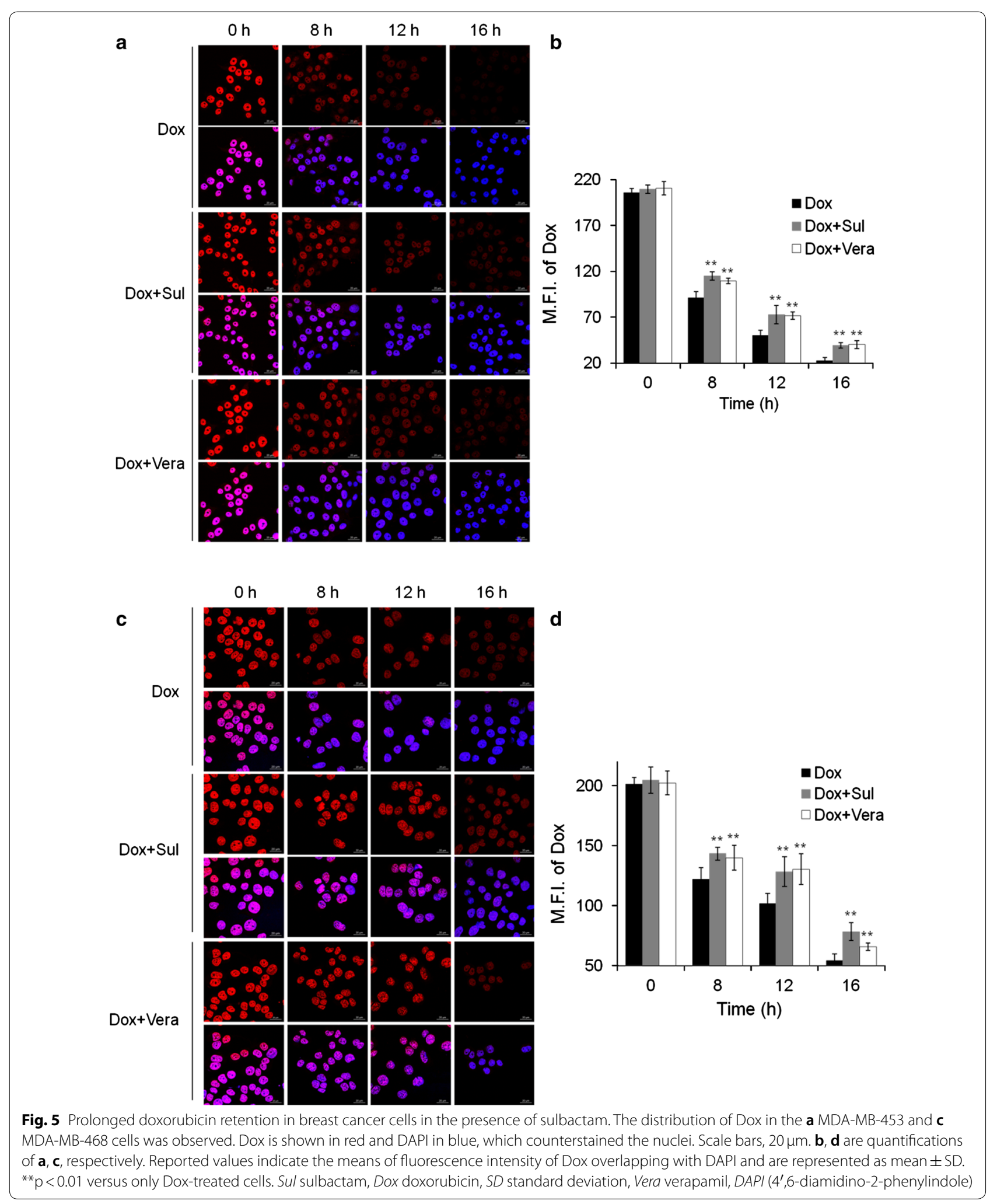




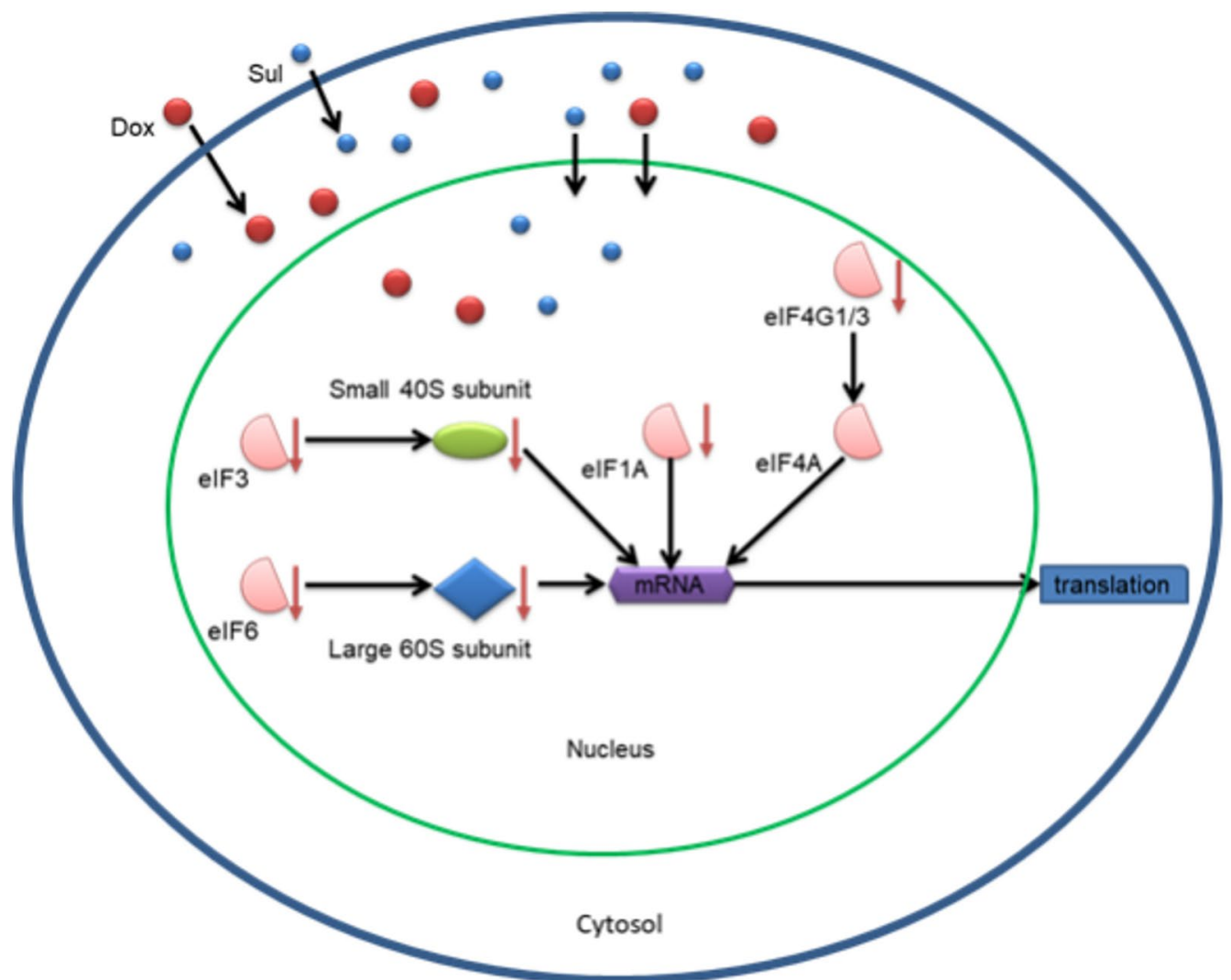

Fig. 6 Co-treatment of sulbactam and doxorubicin blocked the initiation of translation in breast cancer cells. The illustration shows that treatment of the MDA-MB-468 cells with Sul (blue circles) and Dox (red circles) reduced the protein expression levels of elF1A, elF3, elF4G1/3, elF6, small 40S subunit, and large 605 subunit in the cells. Therefore, the transcription and initiation of translation pathways were blocked. Sul sulbactam, Dox doxorubicin

downregulated, corresponding to our previous finding that sulbactam inhibits $\mathrm{ABC}$ transporters of $A$. baumannii and thus kills the bacterium [38]. Most ABC transporter families are transmembrane proteins, which are difficult to isolate and identify through total protein LCMS/MS; hence, we used real-time RT-PCR to determine the effects of sulbactam on the mRNA expression of the $\mathrm{ABC}$ transporter proteins. The expression of $\mathrm{ABC}$ transporter proteins in breast cancer cells is highly heterogeneous [33, 44]; thus, we selected the ABCB superfamily, the $A B C C$ superfamily, and $A B C G 2$, which are strongly associated with drug resistance in breast cancer cells [23, $26,32]$. Based on the results of other studies and our PCR analysis, we selected $A B C B 1, A B C B 2, A B C B 8, A B C B 10$, $\mathrm{ABCC} 1, \mathrm{ABCC} 2, \mathrm{ABCC} 3, \mathrm{ABCC} 4, \mathrm{ABCC} 5, \mathrm{ABCC} 10$, and $A B C G 2$, which exhibit high mRNA expression levels for precise real-time RT-PCR analysis.

Although the effects of sulbactam on these $A B C$ transporters were different in MDA-MB-453 and MDA-MB-468 cells, we conclude that in the presence of sulbactam and doxorubicin, the mRNAs levels of the indicated $A B C$ transporter proteins were evidently downregulated. $\mathrm{ABCB} 1, \mathrm{ABCB} 5, \mathrm{ABCB} 8, \mathrm{ABCC} 1$, $\mathrm{ABCC} 2, \mathrm{ABCC} 3$, and $\mathrm{ABCG} 2$ [22, 45-48] were considered to confer resistance to doxorubicin on the breast cancer cells. We further found that $\mathrm{ABCB} 10, \mathrm{ABCC}$, and $\mathrm{ABCC} 5$ in the MDA-MB-453 cells and ABCB10, $\mathrm{ABCC} 5$, and $\mathrm{ABCC} 10$ in the MDA-MB-468 cells also responded to sulbactam treatment. Studies have reported that $\mathrm{ABCB} 5, \mathrm{ABCB} 8, \mathrm{ABCB} 10, \mathrm{ABCC} 2-5$, and $\mathrm{ABCC} 10$ are overexpressed in breast cancer cells or are associated with breast cancer progression [44, 49-53]. Our doxorubicin efflux assay also indicated that in the presence of sulbactam, the retention time of doxorubicin in MDAMB-453 and MDA-MB-468 cells was prolonged significantly. We used the computer simulation and found that sulbactam may compete with ATP for the ATPdocking sites of $A B C B 1, A B C B 10, A B C C 1$, and MsbA, which exhibit structures similar to the ABCG2 (data not shown). This result provides a possibility how sulbactam 
inhibits the expression and function of $\mathrm{ABC}$ transporters, and this possibility is worthy to do more experiments to confirm it.

\section{Conclusion}

In conclusion, this is the first study that using sulbactam in the mammalian cell. The combination of sulbactam and doxorubicin can enhance the cytotoxicity of doxorubicin in the breast cancer cells by inhibiting the transcription and initiation of translation associated proteins and $\mathrm{ABC}$ transporters, reducing their expression, and blocking the efflux of doxorubicin, thus triggering apoptosis in the breast cancer cells. From these results, sulbactam can be used in breast cancer treatment which can decrease the prescribed dose of doxorubicin to avoid the adverse effects.

\begin{abstract}
Abbreviations
MDR: multidrug resistance; ATP: adenosine triphosphate; ABC: ATP-binding cassette; MTT: 3-(4,5-dimethylthiazol-2-yl)-2,5-diphenyltetrazolium bromide; HER2: human epidermal growth factor receptor 2; TNBC: triple-negative breast cancer; P-gp: P-glycoprotein; PBP: penicillin-binding protein; DMEM: Dulbecco's modified Eagle's medium; FBS: fetal bovine serum; RPMI: Roswell Park Memorial Institute; $I C_{50}$ : the half maximal inhibitory concentration; RT-PCR: reverse transcription-polymerase chain reaction; PCR: polymerase chain reaction; PBS: phosphate buffered saline; SDS-PAGE: sodium dodecyl sulfate-polyacrylamide gel electrophoresis; ACN: acetonitrile; LC: liquid chromatography; MS/MS: tandem mass spectrometry; ICR: ion cyclotron resonance; $\triangle \mathrm{G}$ : Gibbs free energy; ER: estrogen receptor; PR: progesterone receptor; Sul: sulbactam; Dox: doxorubicin; Vera: verapamil.

\section{Authors' contributions}

KRL conceived and supervised the study. SHW and SCS performed most of the experiments, analyzed and interpreted the data, and wrote the first manuscript draft. BHL involved the discussion and supervised the study. CHL conducted some of the experiment and undertook some data interpretation. All authors read and approved the final manuscript.
\end{abstract}

\section{Author details \\ ${ }^{1}$ Department of Molecular Medicine and Institute of Life Science, National Tsing Hua University, No. 101, Section 2, Kuang-Fu Road, Hsinchu 30013, Taiwan, ROC. ${ }^{2}$ Department of Internal Medicine, Puli Christian Hospital, No. 1, Tieshan Road, Puli Township, Nantou 54546, Taiwan, ROC. ${ }^{3}$ Department of Internal Medicine, Hsinchu Mackay Memorial Hospital, No.690, Section 2, Guangfu Road, East District, Hsinchu 300, Taiwan, ROC.}

\section{Acknowledgements}

Not applicable.

\section{Competing interests}

The authors declare that they have no competing interests.

\section{Availability of data and materials}

All data generated or analysed during this study are included in this published article.

\section{Consent for publication}

Not applicable.

Ethics approval and consent to participate

Not applicable.

\section{Funding}

This research was supported by a grant from the "Good-Neighbor Fund" of Mackay Memorial Hospital (Hsin-chu, Taiwan).

\section{Publisher's Note}

Springer Nature remains neutral with regard to jurisdictional claims in published maps and institutional affiliations.

Received: 19 June 2018 Accepted: 29 August 2018

Published online: 04 September 2018

\section{References}

1. Fitzmaurice C, Dicker D, Pain A, Hamavid H, Moradi-Lakeh M, MacIntyre MF, et al. The global burden of cancer 2013. JAMA Oncol. 2015;1(4):505-27.

2. Siegel RL, Miller KD, Jemal A. Cancer statistics, 2015. CA Cancer J Clin. 2015;65(1):5-29.

3. Martin HL, Smith L, Tomlinson DC. Multidrug-resistant breast cancer: current perspectives. Breast Cancer. 2014;6:1.

4. Liu P, Kumar IS, Brown S, Kannappan V, Tawari PE, Tang JZ, et al. Disulfiram targets cancer stem-like cells and reverses resistance and cross-resistance in acquired paclitaxel-resistant triple-negative breast cancer cells. Br J Cancer. 2013;109(7):1876.

5. Gonzalez-Angulo AM, Morales-Vasquez F, Hortobagyi GN. Overview of resistance to systemic therapy in patients with breast cancer. In: Breast cancer chemosensitivity. New York: Springer; 2007. p. 1-22.

6. Musgrove EA, Sutherland RL. Biological determinants of endocrine resistance in breast cancer. Nat Rev Cancer. 2009;9(9):631.

7. Clarke R, Dickson RB, Brünner N. The process of malignant progression in human breast cancer. Ann Oncol. 1990;1(6):401-7.

8. Coley HM. Mechanisms and consequences of chemotherapy resistance in breast cancer. Eur J Cancer Suppl. 2009;7(1):3-7.

9. Szakács G, Paterson JK, Ludwig JA, Booth-Genthe C, Gottesman MM. Targeting multidrug resistance in cancer. Nat Rev Drug Discov. 2006;5(3):219.

10. Higgins CF. Multiple molecular mechanisms for multidrug resistance transporters. Nature. 2007;446(7137):749.

11. Longley DB, Ferguson PR, Boyer J, Latif T, Lynch M, Maxwell P, et al. Characterization of a thymidylate synthase (TS)-inducible cell line: a model system for studying sensitivity to TS-and non-TS-targeted chemotherapies. Clin Cancer Res. 2001;7(11):3533-9.

12. Wang HY, Cheng Z, Malbon CC. Overexpression of mitogen-activated protein kinase phosphatases MKP1, MKP2 in human breast cancer. Cancer Lett. 2003;191(2):229-37.

13. Longley DB, Johnston PG. Molecular mechanisms of drug resistance. J Pathol. 2005;205(2):275-92.

14. Colmegna B, Morosi L, D'Incalci M. Molecular and pharmacological mechanisms of drug resistance: an evolving paradigm. Handb Exp Pharmacol. 2017. https://doi.org/10.1007/164_2017_20.

15. Chaney SG, Sancar A. DNA repair: enzymatic mechanisms and relevance to drug response. J Natl Cancer Inst. 1996;88(19):1346-60.

16. Arcamone F, Cassinelli G, Fantini G, Grein A, Orezzi P, Pol C, et al. Adriamycin, 14-hydroxydaunomycin, a new antitumor antibiotic from $S$. peucetius var. caesius. Biotechnol Bioeng. 2000;67(6):704-13.

17. Momparler RL, Karon M, Siegel SE, Avila F. Effect of adriamycin on DNA, RNA, and protein synthesis in cell-free systems and intact cells. Cancer Res. 1976;36(8):2891-5.

18. Wang S, Kotamraju S, Konorev E, Kalivendi S, Joseph J, Kalyanaraman B. Activation of nuclear factor-kappaB during doxorubicin-induced apoptosis in endothelial cells and myocytes is pro-apoptotic: the role of hydrogen peroxide. Biochem J. 2002;367(Pt 3):729.

19. Tacar O, Sriamornsak P, Dass CR. Doxorubicin: an update on anticancer molecular action, toxicity and novel drug delivery systems. J Pharm Pharmacol. 2013;65(2):157-70.

20. Meredith AM, Dass CR. Increasing role of the cancer chemotherapeutic doxorubicin in cellular metabolism. J Pharm Pharmacol. 2016;68(6):729-41. 
21. Taylor CW, Dalton WS, Parrish PR, Gleason MC, Bellamy WT, Thompson $\mathrm{FH}$, et al. Different mechanisms of decreased drug accumulation in doxorubicin and mitoxantrone resistant variants of the MCF7 human breast cancer cell line. Br J Cancer. 1991;63(6):923.

22. Wind NS, Holen I. Multidrug resistance in breast cancer: from in vitro models to clinical studies. Int J Breast Cancer. 2011;2011:967419.

23. Noguchi K, Katayama K, Sugimoto Y. Human ABC transporter ABCG2/ BCRP expression in chemoresistance: basic and clinical perspectives for molecular cancer therapeutics. Pharmacogenomics Pers Med. 2014;7:53.

24. Clarke R, Leonessa F, Trock B. Multidrug resistance/P-glycoprotein and breast cancer: review and meta-analysis. In: Seminars in oncology. Vol. 32. New York: Elsevier; 2005. p. 9-15.

25. Kathawala RJ, Gupta P, Ashby CR Jr, Chen ZS. The modulation of ABC transporter-mediated multidrug resistance in cancer: a review of the past decade. Drug Resist Updat. 2015;18:1-7.

26. Borst P, Evers R, Kool M, Wijnholds J. A family of drug transporters: the multidrug resistance-associated proteins. J Natl Cancer Inst. 2000;92(16):1295-302.

27. Fletcher Jl, Haber M, Henderson MJ, Norris MD. ABC transporters in cancer: more than just drug efflux pumps. Nat Rev Cancer. 2010;10(2):147.

28. Bao L, Haque A, Jackson K, Hazari S, Moroz K, Jetly R, et al. Increased expression of $\mathrm{P}$-glycoprotein is associated with doxorubicin chemoresistance in the metastatic 4T1 breast cancer model. Am J Pathol. 2011;178(2):838-52.

29. Kunická T, Souček P. Importance of ABCC1 for cancer therapy and prognosis. Drug Metab Rev. 2014;46(3):325-42.

30. Futscher BW, Foley NE, Gleason-Guzman MC, Meltzer PS, Sullivan DM, Dalton WS. Verapamil suppresses the emergence of P-glycoproteinmediated multi-drug resistance. Int J Cancer. 1996;66(4):520-5.

31. Akimoto H, Bruno NA, Slate DL, Billingham ME, Torti SV, Torti FM. Effect of verapamil on doxorubicin cardiotoxicity: altered muscle gene expression in cultured neonatal rat cardiomyocytes. Cancer Res. 1993:53(19):4658-64.

32. Li W, Zhang H, Assaraf YG, Zhao K, Xu X, Xie J, et al. Overcoming ABC transporter-mediated multidrug resistance: molecular mechanisms and novel therapeutic drug strategies. Drug Resist Updat. 2016;27:14-29.

33. Szakács G, Annereau JP, Lababidi S, Shankavaram U, Arciello A, Bussey KJ, et al. Predicting drug sensitivity and resistance: profiling $A B C$ transporter genes in cancer cells. Cancer Cell. 2004;6(2):129-37.

34. Adnan S, Paterson DL, Lipman J, Roberts JA. Ampicillin/sulbactam: its potential use in treating infections in critically ill patients. Int J Antimicrob Agents. 2013;42(5):384-9.

35. Penwell WF, Shapiro AB, Giacobbe RA, Gu RF, Gao N, Thresher J, et al. Molecular mechanisms of sulbactam antibacterial activity and resistance determinants in Acinetobacter baumannii. Antimicrob Agents Chemother. 2015;59(3):1680-9.

36. Noguchi JK, Gill MA. Sulbactam: a beta-lactamase inhibitor. Clin Pharm. 1988;7(1):37-51.

37. Papp-Wallace KM, Senkfor B, Gatta J, Chai W, Taracila MA, Shanmugasundaram $V$, et al. Early insights into the interactions of different $\beta$-lactam antibiotics and $\beta$-lactamase inhibitors against soluble forms of Acinetobacter baumannii PBP1a and Acinetobacter sp. PBP3. Antimicrob Agents Chemother. 2012:56(11):5687-92.

38. Lin CH, Su SC, Ho KH, Hsu YW, Lee KR. Bactericidal effect of sulbactam against Acinetobacter baumannii ATCC 19606 studied by 2D-DIGE and mass spectrometry. Int J Antimicrob Agents. 2014;44(1):38-46.

39. van Veen HW, Callaghan R, Soceneantu L, Sardini A, Konings WN, Higgins CF. A bacterial antibiotic-resistance gene that complements the human multidrug-resistance P-glycoprotein gene. Nature. 2014;391(6664):291.
40. Ter Beek J, Guskov A, Slotboom DJ. Structural diversity of ABC transporters. J Gen Physiol. 2014;143(4):419-35.

41. Shevchenko A, Tomas H, Havli J, Olsen JV, Mann M. In-gel digestion for mass spectrometric characterization of proteins and proteomes. Nat Protoc. 2006;1(6):2856.

42. Levin AS. Multiresistant Acinetobacter infections: a role for sulbactam combinations in overcoming an emerging worldwide problem. Clin Microbiol Infect. 2002;8(3):144-53.

43. Pang B, Qiao X, Janssen L, Velds A, Groothuis T, Kerkhoven R, et al. Drug-induced histone eviction from open chromatin contributes to the chemotherapeutic effects of doxorubicin. Nat Commun. 2013:4:1908.

44. Gillet JP, Schneider J, Bertholet V, De Longueville FR, Remacle J, Efferth T. Microarray expression profiling of $A B C$ transporters in human breast cancer. Cancer Genomics Proteomics. 2006:3(2):97-106.

45. Elliott AM, Al-Hajj MA. ABCB8 mediates doxorubicin resistance in melanoma cells by protecting the mitochondrial genome. Mol Cancer Res. 2009;7(1):79-87.

46. Frank NY, Margaryan A, Huang Y, Schatton T, Waaga-Gasser AM, Gasser $M$, et al. ABCB5-mediated doxorubicin transport and chemoresistance in human malignant melanoma. Cancer Res. 2005:65(10):4320-33.

47. Cui Y, König J, Buchholz U, Spring H, Leier I, Keppler D. Drug resistance and ATP-dependent conjugate transport mediated by the apical multidrug resistance protein, MRP2, permanently expressed in human and canine cells. Mol Pharmacol. 1999;55(5):929-37.

48. Young LC, Campling BG, Cole SP, Deeley RG, Gerlach JH. Multidrug resistance proteins MRP3, MRP1, and MRP2 in lung cancer: correlation of protein levels with drug response and messenger RNA levels. Clin Cancer Res. 2001;7(6):1798-804

49. Yang JY, Ha SA, Yang YS, Kim JW. p-Glycoprotein ABCB5 and YB-1 expression plays a role in increased heterogeneity of breast cancer cells: correlations with cell fusion and doxorubicin resistance. BMC Cancer. 2010;10(1):388

50. Balaji SA, Udupa N, Chamallamudi MR, Gupta V, Rangarajan A. Role of the drug transporter ABCC3 in breast cancer chemoresistance. PLoS ONE. 2016;11(5):e0155013.

51. Ge G, Zhou C, Ren Y, Tang X, Wang K, Zhang W, et al. Enhanced SLC34A2 in breast cancer stem cell-like cells induces chemotherapeutic resistance to doxorubicin via SLC34A2-Bmi1-ABCC5 signaling. Tumor Biol. 2016;37(4):5049-62.

52. Liu $Y$, Peng $H$, Zhang JT. Expression profiling of $A B C$ transporters in a drug-resistant breast cancer cell line using AmpArray. Mol Pharmacol. 2005:68(2):430-8

53. Hlaváč V, Brynychová V, Václavíková R, Ehrlichová M, Vrána D, Pecha V, et al. The expression profile of ATP-binding cassette transporter genes in breast carcinoma. Pharmacogenomics. 2013;14(5):515-29.

Ready to submit your research? Choose BMC and benefit from

- fast, convenient online submission

- thorough peer review by experienced researchers in your field

- rapid publication on acceptance

- support for research data, including large and complex data types

- gold Open Access which fosters wider collaboration and increased citations

- maximum visibility for your research: over 100M website views per year

At $\mathrm{BMC}$, research is always in progress.

Learn more biomedcentral.com/submissions 